\title{
Tratamiento jurídico penal de miembros de grupos subversivos en Colombia
}

\author{
Implicaciones penales del conflicto armado colombiano \\ y del reconocimiento de la beligerancia \\ para miembros de grupos armados ilegales colombianos \\ a la luz del derecho internacional humanitario \\ y del derecho penal colombiano
}

Felix M. Weber

\author{
Tesis de Grado \\ Legum Magister (LL.M.) \\ Universidad Santo Tomás de Aquino \\ Facultad de Derecho, Bogotá D.C. \\ $2011 / 2012$
}




\section{Agradecimientos}

Yo quisiera agradecer al EVANGELISCHES STUDIENWERK VILLIGST e.V. por el apoyo financiero para poder realizar mis estudios en Colombia.

También quisiera agradecer a todas las personas responsables del Convenio académico entre la UNIVERSIDAD KONSTANZ y la UNIVERSIDAD SANTO TOMÀS DE AQUINO

Al director de esta tesis, MAURICIO TORRES GUARNIZO

Al director del Convenio en Alemania, Profesor Dr. MARTIN IBLER

Y a todas las personas, que me ayudaron con la realización y la corrección de esta tesis.

Así mismo quisiera expresar mis agradecimientos a mis padres. Sin el apoyo de ellos mis estudios en Colombia nunca hubieran sido posibles. 


\author{
Abreviaturas \\ $\operatorname{art}$ \\ Artículo \\ AUC. \\ Autodefensas unidas de Colombia \\ (grupos paramilitares colombianos) \\ $\mathrm{CADH}$ \\ Convención Americana sobre Derechos Humanos \\ C.N. \\ Constitución Nacional (de Colombia) \\ C.P \\ Código Penal (de Colombia) \\ DIH \\ Derecho Internacional Humanitario \\ ELN \\ Ejército de liberación nacional \\ (grupo guerillero colombiano) \\ FARC-EP \\ Fuerzas armadas revolucionarias de Colombia- Ejérci \\ del pueblo (grupo guerillero colombiano) \\ Ibíd. \\ (lat.) Ibidem \\ M.P \\ Magistrado ponente \\ No. \\ Numero \\ ONU \\ Organización de las Naciones Unidas \\ pág. \\ Página \\ $\mathrm{Rn}$. \\ (alemán) Randnummer (número de párrafo) \\ TPIR \\ Tribunal Penal Internacional para Ruanda \\ TPIY \\ Tribunal Penal Internacional para ex-Yugoslavia
}




\section{Tabla de contenido}

Introducción

I. Resumen del trabajo y planteamiento de la pregunta problema..........................................

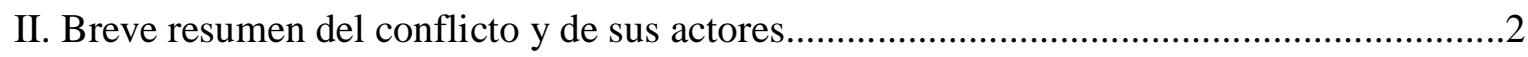

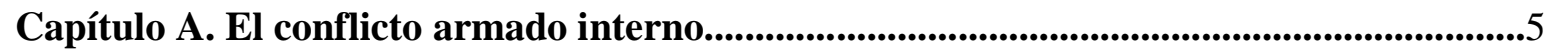

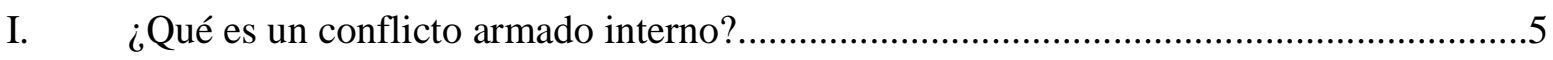

1. Delimitación de "situaciónes de tensión y disturbios internos" .........................................5

2. Definiciones del Conflicto Armado Interno (Convenciones de Ginebra).........................6

a) Artículo 3 común de las Convenciones de Ginebra................................................6

b) El Caso Tadic del Tribunal Penal Internacional para ex-Yugoslavia (TPIY)

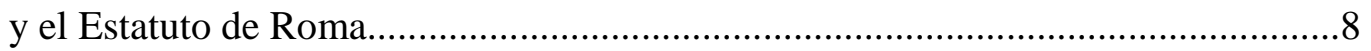

c) Protocolo Adicional II de las Convenciones de Ginebra.........................................9

3. ¿Quién decide sobre la existencia de un conflicto armado interno?.............................13

II. ¿ Existe un conflicto armado interno en Colombia de acuerdo al DIH?.......................15

1. El DIH en el ordenamiento jurídico interno colombiano ("bloque de

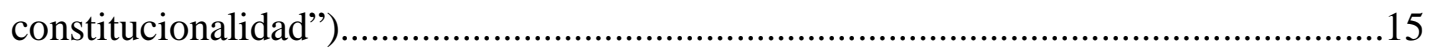

2. Existencia de un conflicto armado interno en Colombia................................................ 17

a) Participación de las fuerzas armadas regulares en el conflicto...............................19

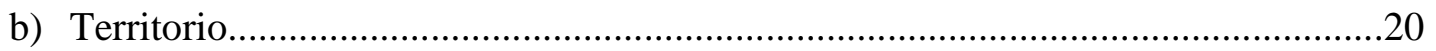

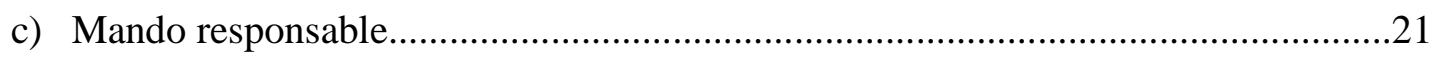

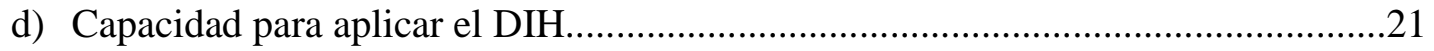

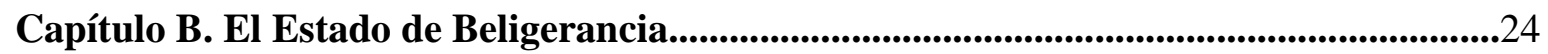

I. El reconocimiento de la beligerancia en el DIH.....................................................24

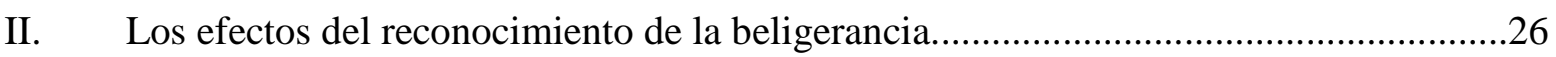

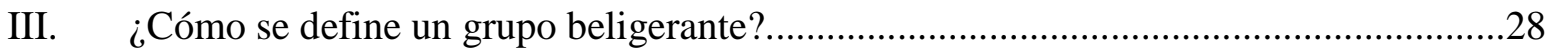

IV. ¿Los grupos guerrilleros en Colombia deberían tener el estatus de beligerancia?.........32 
Capítulo C. ¿Pueden miembros de grupos no reconocidos como beligerantes ser tratados como delincuentes políticos?.................................................................38

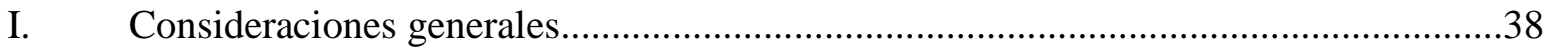

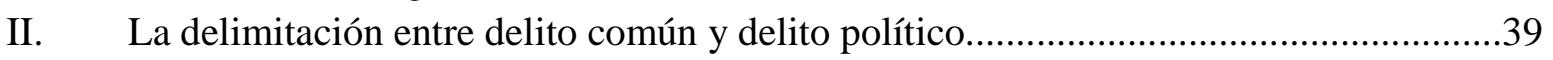

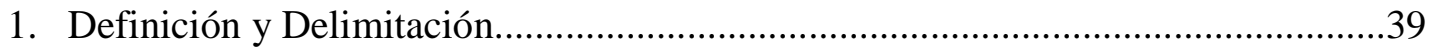

2. Sentencia C-456/97 de la Corte Constitucional....................................................42

III. Las infracciones al DIH en el orden del derecho penal colombiano frente al

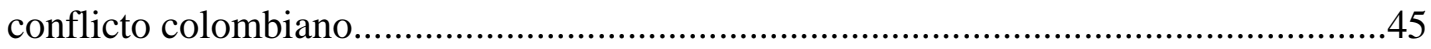

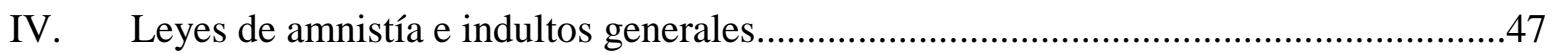

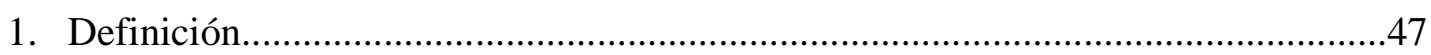

2. La Ley de Justicia y Paz (Ley 975 de 2005) y la sentencia C-370 de 2006 de la Corte Constitucional.....................................................................................

Capítulo D. Reflexiones Finales y conclusiones........................................................................52

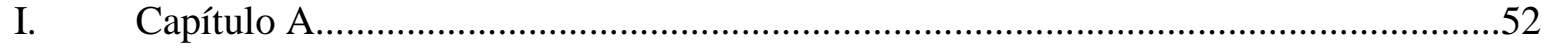

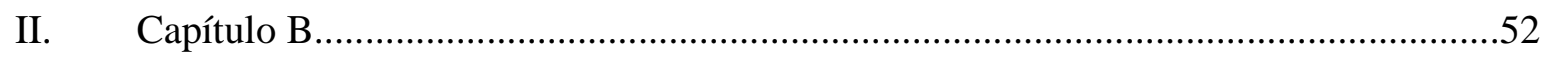

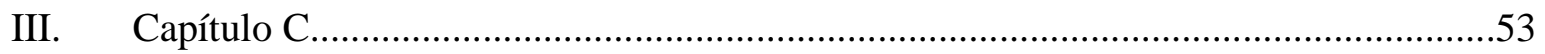

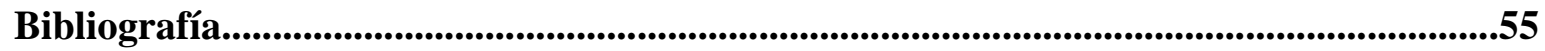




\section{Introducción}

\section{Resumen del trabajo y planteamiento de la pregunta problema}

Las discusiones alrededor del conflicto armado interno en Colombia muchas veces tienen un fondo ideológico dependiente del trasfondo político y de los propios intereses. La tarea de esta tesis es analizar qué implicaciones penales tendría para los miembros de grupos armados ilegales colombianos la existencia de un conflicto armado interno o el reconocimiento de éstos grupos como beligerantes a la luz del derecho internacional humanitario (DIH). Para llegar a la respuesta de esta pregunta, como primera medida, se va a determinar de una manera jurídica objetiva, si es posible hablar de un conflicto armado, abordando cuestiones tales como su definición en el ordenamiento jurídico nacional e internacional y el análisis de los agentes competentes para la determinación de la existencia de un conflicto armado en un determinado lugar. Una vez determinada la existencia de un conflicto armado interno en Colombia, se buscará establecer, cuál es el tratamiento penal que debería recibir un miembro de un grupo al margen de la ley, teniendo en cuenta, que dependiendo de la existencia o no del conflicto armado interno o del estatus de beligerancia de un grupo armado ilegal, las normas penales aplicables pueden variar.

Una respuesta clara y dogmática de la pregunta del tratamiento jurídico adecuado a personas miembros de grupos armados ilegales en Colombia es de suma importancia, porque si no se sabe claramente cómo tratar este tema, las cortes y magistrados penales van a decidir de diferentes maneras, lo que generaría inseguridad jurídica. También es importante saber si las normas del derecho internacional humanitario son aplicables o no y además, cuál es el tratamiento penal en el ordenamiento jurídico colombiano.

Es casi imposible, como extranjero, poder indagar en un año, un tema tan complejo como el conflicto interno colombiano, por lo menos no, de una manera profunda. Por lo tanto, el trabajo no quiere y no puede ser una revisión del tema por completo. Más bien, pretende analizar un aspecto en el marco de este conflicto desde el punto de vista de un estudiante alemán. En el marco del conflicto interno colombiano hay aun bastantes puntos de vista, 
que muchas veces tienen un fondo ideológico, entonces con esta tesis se busca analizar el tema desde una perspectiva lo más objetiva y dogmática posible.

El objetivo principal es resumir y comparar las distintas opiniones y también intentar dar una respuesta adecuada para dar una solución al tema objeto de estudio. La metodología a utilizar, tiene como fundamento una revisión dogmática, es decir, se realizará un análisis del conflicto colombiano basado en la situación jurídica vigente de la jurisdicción nacional e internacional. En ese orden de ideas, el presente trabajo de investigación no busca analizar el sentido y la eficacia de las normas vigentes.

\section{Breve resumen del conflicto interno colombiano y de sus actores}

Desde hace más de 50 años existe un conflicto interno en Colombia que envuelve varios grupos; como guerrilleros, grupos paramilitares y las Fuerzas Armadas regulares de Colombia. El conflicto colombiano, por su larga duración, parece un conflicto endémico, que hace parte de la vida diaria en muchas regiones del país. Sobre el conflicto colombiano y sus consecuencias en el orden del derecho nacional e internacional han existido varias discusiones controversiales durante los años anteriores. La dificultad para definir el conflicto colombiano en términos jurídicos surge de diferentes conceptos, normas, definiciones contrarias y opiniones con distintas ideológicas. Es una tarea muy difícil intentar adaptar normas jurídicas rígidas a un conflicto, en el que las diferentes posiciones de las partes no son claras.

En el caso colombiano están inmersas organizaciones armadas con fines políticos, muchas veces involucradas en actividades relacionadas con el crimen organizado y diferentes bandas criminales, de diverso tamaño y configuración en distintas zonas del territorio colombiano. Los actores del conflicto básicamente son tres grandes grupos: los grupos guerrilleros, los paramilitares y las Fuerzas Armadas regulares de Colombia.

El primero de ellos se autodenomina FARC-EP (Fuerzas Armadas Revolucionarias de Colombia - Ejercito del Pueblo) y tiene su origen en los grupos de autodefensa campesina. Estos grupos se fundaron al final de los años cuarenta, como respuesta a la brutalidad 
estatal en el periodo denominado "la Violencia". ${ }^{1}$ Durante este periodo (1948-1953), que se originó por la masiva y sistemática confrontación violenta entre los seguidores del partido liberal y los del partido conservador en Colombia, comenzando por el asesinato del candidato presidencial del liberalismo, el Dr. Jorge Eliécer Gaitán el 9 de abril de $1948 .{ }^{2}$

Los miembros de grupos autodefensas campesinas liderados por Manuel Marulanda y Jacobo Arenas, fundaron en 1964 la organización guerrillera Bloque Sur, la cual, el 5 de mayo de 1966, se convirtió en las hoy denominadas FARC-EP en la región de Marquetalia. Fundado como grupo autodefensa bajo influencias soviéticas y en contra de la violencia militar, las FARC-EP se proclamaron como grupo guerrillero marxista-leninista y bolivariano. ${ }^{3}$ Sus fines políticos oficiales, eran los de acabar con las desigualdades sociales, políticas y económicas, y lograr una reforma agraria mediante el establecimiento de un Estado marxista-leninista y bolivariano en Colombia. Hoy en día las FARC-EP constituyen el grupo guerrillero más antiguo de América Latina que todavía se encuentra activo.

El segundo gran grupo guerrillero, el ELN (Ejército de Liberación Nacional) fue fundado en 1964 como una guerrilla, por facciones de movimientos estudiantiles y grupos campesinos, con apoyo desde Cuba por Fidel Castro. ${ }^{4}$ Basados en el pensamiento de uno de sus miembros, el teólogo Camilo Torres, el ELN adoptó una ideología marxista con inspiraciones de la teología de la liberación. ${ }^{5}$ Después de una derrota propinada por las Fuerzas Armadas regulares en el año 1973, este grupo guerrillero fue casi eliminado por complete, sin embargo, el ELN resurgió en el año de 1980. ${ }^{6}$ En el año 2006 el ELN entró en combates con el otro grupo guerrillero, las FARC, por el control territorial de regiones claves para cada uno de los grupos. No obstante, los dos grupos se reconciliaron en el año 2009. Hoy en día el ELN es, además de las FARC, el segundo movimiento guerrillero activo en Colombia bajo el mando de su actual comandante Nicolás Rodríguez Bautista.

\footnotetext{
${ }^{1}$ Pizarro Leongómez, Una democracia asediada, pág 85.

${ }^{2}$ Valencia, El reconocimiento de beligerancia frente al conflicto armado con las FARC-EP, pág. 30.

${ }^{3}$ Valencia, El reconocimiento de beligerancia frente al conflicto armado con las FARC-EP, pág. 31.

${ }^{4}$ Londoño, Derecho internacional humanitario, conflicto armado y tratamiento de las victimas, pág. 135.

${ }^{5}$ Comisión Internacional de Juristas/Comisión Andina de Juristas, Violencia en Colombia, pág. 94.

${ }^{6}$ Londoño, Derecho internacional humanitario, conflicto armado y tratamiento de las victimas, pág. 135.
} 
Las AUC (Autodefensas Unidas de Colombia) fueron grupos paramilitares con ideologías de extrema derecha, que se crearon con el fin de luchar contra los grupos guerrilleros colombianos como una forma de "contrainsurgencia". Las AUC se fundaron en el año 1997, desprendiéndose de varios grupos paramilitares que tuvieron sus orígenes en los años sesenta. Las AUC existieron hasta su desmovilización oficial en el año 2006, un proceso, que todavía continua. A partir de los grupos, que anteriormente hacían parte de las AUC se han fundado nuevos grupos criminales organizados. Un informe de la organización Human Rights Watch realizado en 2012, estableció que "independientemente de que se los clasifique como nuevos grupos paramilitares o como bandas criminales organizadas, los grupos sucesores están perpetrando abusos flagrantes y aterrorizando a la población civil a través de prácticas muy similares a las de las AUC". ${ }^{7}$

Por otro lado, las Fuerzas Armadas regulares del gobierno colombiano también se encuentran involucradas en el conflicto, luchando contra todas las grupos armados ilegales en Colombia.

Los diferentes grupos armados al margen de la ley se han financiado con prácticas como el secuestro y el cobro de contribuciones (impuestos) sobre el tráfico ilícito de drogas, especialmente de la cocaína. En febrero de 2012 las FARC anunciaron que iban a poner fin a la práctica del secuestro para su financiación y que iban a liberar a todas las personas actualmente secuestradas. ${ }^{8}$ Hoy en día, las acciones criminales, consideradas por ellos como políticas, de los grupos armados al margen de la ley en Colombia y los hechos criminales comunes, como el narcotráfico, están conectadas entre sí. Esta situación es un hecho que dificulta igualmente la situación en este país.

En el primer capítulo del trabajo se analizará, que es un conflicto armado según las normas del DIH y sí la situación jurídica en Colombia coincide con las definiciones del DIH.

\footnotetext{
${ }^{7}$ Human Rights Watch, Heredores de los paramilitares - La nueva cara de la violencia en Colombia.

${ }^{8}$ El Espectador, 26 de febrero de 2012, ¿Estrategia o buena voluntad de paz?.
} 


\section{Capítulo A. El Conflicto Armado Interno}

\section{I. ¿Qué es un conflicto armado interno?}

Conseguir una clara definición de conflicto armado interno no es tan fácil porque, tanto en el derecho internacional humanitario, como en la jurisdicción internacional, existen varias definiciones que establecen diferentes condiciones.

\section{Delimitación de "Situaciones de Tensión y Disturbios Internos" de un conflicto armado interno}

No toda forma de violencia interna puede ser definida jurídicamente como un conflicto armado interno. Según el art. 1, II del protocolo adicional II de Ginebra, situaciones de tensión y disturbios internos no son conflictos armados internos y por ello, estos casos no son considerados por el DIH sino por el derecho penal interno de cada Estado y por los tratados sobre derechos humanos. ${ }^{9}$ Generalmente, se puede decir que actos de violencia individual, hechos criminales, protestas violentas o utilización de la fuerza espontánea que no constituyan una acción típica militar, no pueden ser subsumidos bajo el término "conflicto armado". 10

La categoría de tensiones y disturbios internos define todas las situaciones violentas que por su intensidad no tienen la entidad de un conflicto armado. Entonces, no existe un conflicto armado interno en el sentido del DIH, pero tampoco un estado de paz social. ${ }^{11}$ No obstante, la categoría de tensiones internas y de disturbios interiores es un concepto jurídico indeterminado, y por lo tanto, vago e impreciso. En consideración de Krieger, cuando un

\footnotetext{
9 "El presente protocolo adicional II no se aplica a las situaciones de disturbios y de tensiones internas..."; Ramelli, La Constitución Colombiana y el derecho internacional humanitario, p. 64, 99; similar también Herdegen, Völkerrecht, § 56, No. 17; Alston, Bericht des Sonderberichterstatters über außergerichtliche, summarische oder willkürliche Hinrichtungen, ONU 2010.

${ }^{10}$ Gonzáles Mongui, Derecho Internacional Humanitario, pág. 215.

${ }^{11}$ Ramelli, La Constitución Colombiana y el derecho internacional humanitario, pág. 64.
} 
conflicto armado interno tiene cierta intensidad, el gobierno está obligado a movilizar las fuerzas armadas y no sólo la policía. ${ }^{12}$

En conclusión la definición de la situación interna depende en última instancia de la vista subjetiva de cada Estado. ${ }^{13}$ Esta ausencia de una clara delimitación, hace difícil definir el instante, a partir de cual, se cruza el límite entre situaciones de tensión y conflicto armado interno. La clasificación entre conflictos armados internos y otras formas de violencia generalizada también ha venido siendo más difícil de estructurar, por las nuevas formas en las que hoy en día se configuran los conflictos. También en Colombia pueden existir tanto situaciones de tensiones y disturbios internos (por ejemplo bandas con vinculación al crimen organizado) como verdaderas situaciones de un conflicto armado interno. Este trabajo pretende analizar éstas últimas situaciones.

\section{Definiciones de conflicto armado interno en el derecho internacional humanitario}

El conflicto armado interno, en sentido jurídico, se encuentra definido en el artículo 3 común y en el protocolo adicional II de las Convenciones de Ginebra. Así mismo, existe una definición en el marco del derecho penal internacional.

a) Artículo 3 común a las Convenciones de Ginebra

El artículo 3 común a las cuatro Convenciones de Ginebra del 12 de agosto de 1949 fue la primera norma en regular la materia del conflicto armado interno. ${ }^{14}$ Se establece que

\footnotetext{
${ }^{12}$ Krieger, Deutschland im asymmetrischen Konflikt, Online-Beiträge zum Völker- und Verfassungsrecht Nr. 2/2010, pág. 8.

${ }^{13}$ Ramelli, La Constitución Colombiana y el derecho internacional humanitario, pág. 66.

${ }^{14}$ Articulo 3 común:

En caso de conflicto armado que no sea de índole internacional y que surja en el territorio de una de las Altas Partes Contratantes cada una de las Partes en conflicto tendrá la obligación de aplicar, como mínimo, las siguientes disposiciones:

1) Las personas que no participen directamente en las hostilidades, incluidos los miembros de las fuerzas armadas que hayan depuesto las armas y las personas puestas fuera de combate por enfermedad, herida, detención o por cualquier otra causa, serán, en todas las circunstancias, tratadas con humanidad, sin distinción alguna de índole desfavorable basada en la raza, el color, la religión o la creencia, el sexo, el nacimiento o la fortuna o cualquier otro criterio análogo. A este respecto, se prohíben, en cualquier tiempo y lugar, por lo que atañe a las personas arriba mencionadas:

a) los atentados contra la vida y la integridad corporal, especialmente el homicidio en todas sus formas, las mutilaciones, los tratos crueles, la tortura y los suplicios;
} 
también en conflictos armados de carácter no-internacional, algunos estándares mínimos del DIH son aplicables. No obstante, esta norma nos da una definición bastante amplia del conflicto armado de carácter no-internacional. ${ }^{15}$ En general, el contenido de este artículo es muy vago, el conflicto debe ser armado y no de índole internacional, pero por ejemplo no contiene ninguna de las condiciones que deben cumplir los grupos armados para formar parte del conflicto armado. ${ }^{16}$

Sin embargo Herdegen afirma, que los grupos armados que forman parte de un conflicto en el sentido del artículo 3 común, deben tener un control efectivo sobre una parte notable del territorio del Estado, y además, deben ser capaces de reconocer y cumplir las normas del DIH. $^{17}$

Por otro lado Ramelli sostiene, que el control territorial no tiene que ser completo ni continuo, agrega, que un control esporádico y compartido con las fuerzas regulares sería suficiente. ${ }^{18}$ Esta definición de Ramelli es muy amplia y aún limitándola a la aplicación del DIH, como lo ordena el protocolo adicional II de Ginebra, podemos afirmar que el control sobre el territorio, por lo menos debe ser suficiente para realizar operaciones militares sostenidas y concertadas. Esto significa que los insurgentes deben perseguir unos objetivos político-militares más o menos claros y deben poseer una organización jerárquica bajo un mando responsable. ${ }^{19}$

En todo caso, no es necesario que el grupo armado organizado sea reconocido previamente como grupo beligerante por parte del gobierno nacional o de terceros estados para llegar a

\footnotetext{
b) la toma de rehenes;

c) los atenta dos contra la dignidad personal, especialmente los tratos humillantes y degradantes;

d) las condenas dictadas y las ejecuciones sin previo juicio ante un tribunal legítimamente constituido, con garantías judiciales reconocidas como indispensables por los pueblos civilizados.

2) Los heridos y los enfermos serán recogidos y asistidos.

Un organismo humanitario imparcial, tal como el Comité Internacional de la Cruz Roja, podrá ofrecer sus servicios a las Partes en conflicto. Además, las Partes en conflicto harán lo posible por poner en vigor, mediante acuerdos especiales, la totalidad o parte de las otras disposiciones del presente Convenio. La aplicación de las anteriores disposiciones no surtirá efectos sobre el estatuto jurídico de las Partes en conflicto.

${ }^{15}$ Ferro H, Existencia de un Conflicto Armado Interno, pág. 7.

${ }^{16}$ Ramelli, La Constitución Colombiana y el derecho internacional humanitario, pág. 69.

${ }^{17}$ Herdegen, Völkerrecht, § 56, No. 17; también Ipsen, Völkerrecht, § 64, No. 13.

${ }^{18}$ Ramelli, La Constitución Colombiana y el derecho internacional humanitario, pág. 69.

${ }^{19}$ Ramelli, La Constitución Colombiana y el derecho internacional humanitario, pág. 69.
} 
formar parte del conflicto en el sentido del artículo 3 común, así como para la aplicación del DIH (lo mismo en el caso del protocolo adicional II). ${ }^{20}$ Tampoco la norma produce ningún efecto sobre el estatus jurídico de las partes del conflicto. ${ }^{21} \mathrm{El}$ cumplimiento de la norma sólo tiene como resultado la protección por parte del DIH.

Cabe mencionar, que la calificación de sí existe un conflicto armado interno o no y su intensidad, no depende de las partes en conflicto, ya que las Convenciones de Ginebra tienen el fin de proteger las víctimas de los mismos. Si la calificación y la aplicación del DIH dependiera de las partes del conflicto, en la mayor parte de éstos, habría tendencia de estas a minimizar el conflicto. Por ello, el artículo 3 común tiene que ser aplicado [automáticamente] cuando existe un conflicto armado que cumple con los criterios de este artículo. ${ }^{22}$ Si las condiciones del artículo 3 común son cumplidas, las partes ipso iure son obligadas a respetar las reglas del DIH establecidas en esta norma. ${ }^{23}$

b) El Caso Tadic del Tribunal Penal Internacional para Ex-Yugoslavia (TPIY) y el Estatuto de Roma

El concepto de conflicto armado interno también aparece en el artículo 8 lit. c) del Estatuto de Roma, pero allí se puede decir que se trata de la misma definición dada en el artículo 3 común. Se puede asumir, que una definición completamente nueva por parte de la doctrina jurídica sería contraria a la intención de los redactores del Estatuto de Roma. ${ }^{24}$

En el caso contra Dusko Tadic, el Tribunal Penal Internacional para Ex-Yugoslavia (TPIY) ha definido el conflicto armado interno de la siguiente manera: “...entendemos que existe un conflicto armado (interno) cuando se da [...] prolongada violencia armada entre las autoridades gubernamentales y grupos armados organizados o entre tales grupos en [el

${ }^{20}$ Ramelli, La Constitución Colombiana y el derecho internacional humanitario, pág. 70, 71; Ramelli, Derecho Internacional Humanitario y estado de beligerancia,.

21 Ramelli, La Constitución Colombiana y el derecho internacional humanitario, pág. 71.

${ }_{22}$ TPIR, Jugdgement, The prosecutor v. Jean Paul Akayesu, ICTR-96-4-T; Gonzáles Mongui, Derecho Internacional Humanitario, pág. 215.

23 Ramelli, La Constitución Colombiana y el derecho internacional humanitario, pág. 70.

${ }^{24}$ Cullen, Key developments, Military Law Review, Vol. 183; Ferro H, Existencia de un Conflicto Armado Interno, pág. 10. 
territorio de] un Estado". ${ }^{25}$ Esta definición, en principio, parece más amplia que la contenida en el artículo 3 común, porque no se refiere a condiciones tales como ejercer un tipo de control territorial por parte de los grupos armados. ${ }^{26} \mathrm{~A}$ su vez, el Tribunal se refiere al artículo 3 común cuando establece que la evaluación aplicada por la Sección de Apelaciones, para conocer sobre la existencia de un conflicto armado, tendrá en cuenta los propósitos de las reglas contenidas en dicha norma, enfocándose en dos aspectos del conflicto: la intensidad del conflicto y la organización de las partes en conflicto (con el criterio de la "prolongada" violencia). Con estos criterios, un conflicto armado puede ser distinguido del bandolerismo o de actividades, que no caracterizarían a un conflicto armado verdadero. ${ }^{27}$ Con la condición de la intensidad o la prolongación del conflicto, el Tribunal aplicó una nueva condición que el artículo 3 común no contiene. Éste quizás lo hizo para mejorar la distinción entre conflictos armados internos y situaciones de tensión y disturbios. Como resultado, la definición del Tribunal es más precisa que la del artículo 3 común, pero más amplia que la del protocolo adicional II de las Convenciones de Ginebra, tal como sé verá más adelante. ${ }^{28}$

\section{c) Protocolo Adicional II de las Convenciones de Ginebra}

Mientras que la definición del artículo 3 común es muy vaga y corta, la del protocolo adicional II de las Convenciones de Ginebra del año 1977 difiere de las definiciones mencionadas, ya que contiene más condiciones. En este orden de ideas, sí un conflicto puede ser declarado según éste protocolo como conflicto armado interno, también lo sería según el artículo 3 común. ${ }^{29}$ Según el artículo 1 I del protocolo adicional II, conflictos armados son aquellos que "se desarrollan (1) entre las fuerzas armadas y fuerzas armadas disidentes o grupos armados organizados que (2) bajo la dirección de un mando responsable, (3) ejerzan sobre una parte de dicho territorio un control tal, que les permita

\footnotetext{
${ }^{25}$ TPIY, "Prosecutor v. Tadic", case IT-94.1T, Decision on the Defense Motion for Interlocutory Appeal on Jurisdiction, 1. October 1995, parágrafo 70.

${ }^{26}$ Ferro H, Existencia de un Conflicto Armado Interno, Revista Derecho Publico No. 26, Universidad Los Andes, pág. 11.

27 TPIY, Judgment, "Prosecutor v. Tadic", IT94-1-T, parágrafo 562.

${ }^{28}$ Gonzáles Mongui, Derecho Internacional Humanitario, pág. 217.

${ }^{29}$ Uprimny, ¿Existe o no Conflicto Armado en Colombia?, pág.6.
} 
realizar operaciones militares sostenidas y concertadas y (4) aplicar el presente protocolo". 30

La definición del protocolo adicional II ha recibido muchas críticas. El problema más grande se genera en la práctica internacional, en donde las confrontaciones armadas casi nunca reúnen todas las condiciones necesarias para ser clasificadas como un conflicto armado interno. ${ }^{31}$ En consecuencia, en muchas confrontaciones armadas en el mundo, la población civil queda excluida de la protección del protocolo. Existen grupos armados ilegales, que no quieren o, debido a su mala organización, no pueden aplicar el DIH, y por lo tanto, es imposible referirse a las disposiciones del protocolo adicional II. ${ }^{32}$ Por ejemplo, para la situación de la violencia en Ruanda del año 1994, el protocolo adicional II sería inaplicable, debido a la inestabilidad del Estado, ya que no actuaron "fuerzas regulares gubernamentales" y los grupos armados que iniciaron la violencia, tampoco actuaron bajo un "mando responsable" sino de forma caótica. ${ }^{33}$

Pero por otro lado, es importante definir el conflicto armado y delimitarlo de situaciones de tensiones internas, las cuáles no se rigen por el DIH sino por el derecho interno de un Estado. La definición del artículo 3 común parece demasiado amplia y hace muy difícil trazar una línea clara entre diferentes situaciones conflictivas. Del mismo modo, se puede decir que las situaciones, en las cuales el protocolo adicional II no es aplicable, muchas

\footnotetext{
${ }^{30}$ Artículo 1: Ambito de aplicación material

1. El presente Protocolo, que desarrolla y completa el artículo 3 común a los Convenios de Ginebra del 12 de agosto de 1949, sin modificar sus actuales condiciones de aplicación, se aplicará a todos los conflictos armados que no estén cubiertos por el artículo 1 del Protocolo adicional a los Convenios de Ginebra del 12 de agosto de 1949 relativo a la protección de las víctimas de los conflictos armados internacionales (Protocolo I) y que se desarrollen en el territorio de una Alta Parte contratante entre sus fuerzas armadas y fuerzas armadas disidentes o grupos armados organizados que, bajo la dirección de un mando responsable, ejerzan sobre una parte de dicho territorio un control tal que les permita realizar operaciones militares sostenidas y concertadas y aplicar el presente Protocolo.

2. El presente Protocolo no se aplicará a las situaciones de tensiones internas y de disturbios interiores, tales como los motines, los actos esporádicos y aislados de violencia y otros actos análogos, que no son conflictos armados.

${ }^{31}$ Ferro H, Existencia de un Conflicto Armado Interno, Revista Derecho Publico No. 26, Universidad Los Andes, pág. 9; Cullen, Key developments, Military Law Review, Vol. 183; Ramelli, La Constitución Colombiana y el derecho internacional humanitario, p. 75; Ipsen, Völkerrecht, § 65, No. 18.

${ }^{32}$ Herdegen, Völkerrecht, § 56, No. 18.

${ }^{33}$ Ferro H, Existencia de un Conflicto Armado Interno, pág. 9.
} 
veces son cubiertas por el artículo 3 común, que también da una protección mínima a la población civil. ${ }^{34}$

El punto problemático para definir una situación interna como conflicto armado interno se refiere a las condiciones que un grupo armado involucrado tiene que cumplir para hacer parte del conflicto.

La primera condición es que el grupo armado organizado tiene que actuar bajo la dirección de un mando responsable. Esto significa que la organización del grupo debe tener una estructura similar a una línea de mando militar, con estructuras directivas y responsabilidades jerárquicas. ${ }^{35}$ Autoridades espontáneas de líderes carismáticos populares, como ocurre a menudo en situaciones de tensión o disturbios internos, no son suficientes para cumplir la condición de un "mando responsable", pues ellos normalmente no ejercen una verdadera autoridad en un sentido militar sobre las personas. ${ }^{36}$

La segunda condición es que los grupos armados ejerzan sobre una parte del territorio, un control tal que les permita realizar operaciones militares sostenidas y concertadas. Pero, ¿cómo es este control sobre el territorio?. Es claro, que hoy en día, en situaciones de conflicto, los grupos insurgentes en muy pocas ocasiones tienen un control de facto completo y establecido sobre un territorio, por eso, esta condición limita mucho la aplicabilidad del protocolo. ${ }^{37}$ Entonces, esta circunstancia debe ser entendida de una manera relativa y funcional. ${ }^{38}$ Esto no significa, que el grupo deba tener el poder de evitar que las fuerzas regulares entren al territorio, sino que el control debe permitir al grupo armado realizar operaciones militares continuadas y concertadas, así como libertad de actuar dentro del territorio. ${ }^{39} \mathrm{El}$ control territorial no tiene que ser completo y de facto, sino también puede ser compartido con las fuerzas regulares del Estado.

\footnotetext{
${ }^{34}$ Ipsen, Völkerrecht, § 65, No. 16.

${ }^{35}$ Ramelli, La Constitución Colombiana y el derecho internacional humanitario, pág. 84.

36 ibíd, pág. 83.

${ }^{37}$ Ibíd, pág. 85.

${ }^{38}$ Valencia Villa, Alejandro, Conflicto Armado y Derecho Humanitario, p. 117.

${ }^{39}$ Ramelli, La Constitución Colombiana y el derecho internacional humanitario, pág. 85; Valencia Villa, Alejandro, Conflicto Armado y Derecho Humanitario, pág. 117; Uprimny, ¿Existe o no Conflicto Armado en Colombia?, pág. 7.
} 
La última condición es que el grupo armado tenga la capacidad para aplicar el protocolo adicional II, o sea, su organización y control tiene que ser suficiente para asegurar que sus miembros, así como sus subordinados, apliquen el DIH. Si los insurgentes quieren gozar de la protección del DIH tienen que aplicarlo. Esta condición resulta en la obligación de "no realizar" actos prohibidos por el protocolo para cumplir las normas del $\mathrm{DIH} .{ }^{40} \mathrm{Si}$ el grupo cumple con las condiciones anteriores (mando responsable y dominio territorial), esto significa, en conclusión, que el grupo posee la "infraestructura mínima” para aplicar el DIH. $^{41}$

Surge luego un interrogante, que a su vez es un punto muy criticado del protocolo. El artículo 1 del protocolo adicional II establece, que las fuerzas armadas disidentes o los grupos armados organizados tienen que luchar contra las fuerzas armadas gubernamentales. ¿Qué pasa entonces si dos o más grupos armados están involucrados en el conflicto y las fuerzas armadas regulares no están involucradas, no existen o no pueden ser definidas, como puede pasar en los llamados "Estados fallidos"? El protocolo adicional II, según su texto en estas situaciones no es aplicable. Esta situación es uno de los grandes puntos débiles de ese protocolo, porque en la práctica, existen conflictos armados donde el gobierno no toma parte o fácticamente no existe y estos conflictos son igualmente perjudiciales para la población civil. La protección del protocolo adicional II no se da a situaciones en que participen exclusivamente grupos armados no estatales, cuando no hay participación de las fuerzas armadas estatales. ${ }^{42}$

En estos casos los grupos armados deben, por lo menos, respetar el artículo 3 común a las Convenciones de Ginebra. ${ }^{43}$ Igualmente para el Tribunal Penal Internacional para exYugoslavia (TPIY), que aplica en su jurisdicción la idea del artículo 3 común, existe un conflicto armado también cuando se recurre a la fuerza entre dos grupos armados $(u t$ supra).

\footnotetext{
${ }^{40}$ Ramelli, La Constitución Colombiana y el derecho internacional humanitario, pág. 86.

${ }^{41}$ Bolaños Enríquez, El derecho internacional humanitario ante los conflictos modernos, pág. 30.

${ }^{42}$ Valencia Villa, Derecho Internacional Humanitario, pág. 217.

${ }^{43}$ Ramelli, La Constitución Colombiana y el derecho internacional humanitario, pág. 87.
} 
En conclusión, se puede decir que existen varias definiciones de un conflicto armado interno en diferentes normas o fallos y es difícil hablar de una única definición vigente. El protocolo II garantiza la protección más amplia pero también tiene las condiciones más estrictas, mientras que el artículo 3 común da una protección mínima pero no tiene tantas condiciones a cumplir. Hoy en día no es posible hablar de una definición vigente del conflicto armado, por el contrario existen varias definiciones con distintas consecuencias.

Tampoco podemos hablar de una "costumbre internacional" para definir un conflicto armado interno. No existe una única definición, como vemos en la jurisprudencia, específicamente en el fallo del Caso Tadic de 1995, tiene una idea distinta del término (ut supra). Además casi todos los fallos recientes que apliquen las Convenciones y Protocolos de Ginebra se emitieron en los últimos veinte años, que es un tiempo muy corto para hablar de una costumbre internacional o una jurisdicción establecida. ${ }^{44}$

Básicamente y para concluir, el derecho internacional público establece tres formas de conflictos no-internacionales:

aa) un conflicto no-internacional (interno) que cumple las condiciones del artículo 3 común de las cuatro convenciones de Ginebra

bb) un conflicto no-internacional (interno) que cumple las condiciones del artículo 3 común y del protocolo adicional II de las cuatro convenciones de Ginebra

cc) el conflicto no tiene la intensidad y la continuidad para cruzar el umbral de un conflicto armado interno y está definido por situaciones de tensión o disturbios internos.

\section{3. ¿Quién decide sobre la existencia de un conflicto armado interno?}

La existencia (o no) de un conflicto armado interno genera varios efectos para las partes del conflicto. Dependiendo del punto de vista, estos efectos pueden ser positivos o negativos. Por eso es importante definir, quién decide sobre la existencia de un conflicto armado interno. ¿El Estado afectado puede tomar esta decisión autónomamente, lo hace la comunidad internacional, la ONU, o es un estatus ipso jure?

\footnotetext{
${ }^{44}$ Ferro H, Existencia de un Conflicto Armado Interno, pág. 12.
} 
El problema de que los Estados decidan, es que muchos gobiernos nacionales no quieren reconocer un conflicto como conflicto armado interno, porque temen que con este reconocimiento den una especie de "legitimidad internacional" a los insurgentes y también que sobrevenga el debilitamiento de la posición del gobierno establecido. ${ }^{45}$ Pero el protocolo adicional II no valora, que en caso de un conflicto armado, si las operaciones militares de las partes armados sean lícitas o ilícitas. No es una norma para legitimar actos violentos. ${ }^{46}$ El artículo 3 común párrafo II establece que "la aplicación de estas previsiones no debe afectar el estatus legal de las partes en conflicto". Casi lo mismo establece el protocolo adicional II en su artículo 3 párrafo I. ${ }^{47}$ La aplicación de DIH no tiene nada que ver con el estatus legal de las partes involucradas, sólo sirve para dar la protección del DIH a las personas envueltas en conflictos armados.

Por otro lado, debe ser considerado que el reconocimiento de un conflicto como un conflicto armado interno tiene ventajas para los Estados. Si los insurgentes y grupos armados ilegales sólo son "simples criminales" tienen que ser tratados como criminales, es decir, que siempre necesitan un juicio justo y no pueden ser atacados por las fuerzas regulares si no existe una amenaza inmediata. Pero, sí el Estado trata a los insurgentes como combatientes en un conflicto armado interno, el Estado tiene la posibilidad de convertir a los enemigos en "objetos militares" y atacarlos aún cuando no representan una amenaza inmediata para el Estado. ${ }^{48}$ Así, en un conflicto armado interno, el ius en bello es aplicable. Combatientes enemigos pueden ser atacados, también por bombardeos, pero sólo en el margen del articulo 3 común o del protocolo adicional II. ${ }^{49}$

Como se ve, si los Estados mismos decidieran sobre la existencia de un conflicto armado interno, siempre parecería una decisión por razones oportunistas y arbitrarias. El reconocimiento de un conflicto armado por parte de terceros Estados también sería

\footnotetext{
${ }^{45}$ Valencia Villa, Alejandro, Conflicto Armado y Derecho Humanitario, p. 103; Herdegen, Völkerrecht, §56, No. 18.

46 Herdegen, Völkerrecht, § 56, No. 18; Ferro H, Existencia de un Conflicto Armado Interno, pág. 15.

47 "No podrá invocarse disposición alguna del presen te Protocolo con objeto de menoscabar la soberanía de un Estado o la responsabilidad que incumbe al gobierno de mantener o restablecer la ley y el orden en el Estado o de defender la unidad nacional y la integridad territorial del Estado por todos los medios legítimos."

48 Ferro H, Existencia de un Conflicto Armado Interno, pág. 14.

49 Herdegen, Völkerrecht, § 56, Rn. 19
} 
problemático desde la perspectiva de la soberanía de los Estados. Si se trata de un Estado soberano, terceros no tienen el derecho de calificar una situación que acontece dentro de este Estado y menos aún, si la decisión tiene efectos vinculantes para éste.

Por ello, el conflicto armado interno es un estatus ipso iure es decir, nadie tiene que decidir, porque es una consecuencia que surge de manera automática. Para la existencia de un conflicto armado sólo es importante si objetivamente, las condiciones del artículo 3 común o del protocolo adicional II son cumplidas. En este caso existe un conflicto armado interno ipso iure y las partes tienen la obligación de cumplir las normas del $\mathrm{DIH} .{ }^{50}$

\section{II. ¿Existe un conflicto armado interno en Colombia de acuerdo al DIH?}

Después de haber identificado las diferentes definiciones de un conflicto armado interno, se buscará una respuesta a la pregunta de sí en Colombia actualmente existe un conflicto armado interno.

1. El DIH en el ordenamiento jurídico interno colombiano (bloque de constitucionalidad)

En Colombia las normas y reglas del DIH están integradas en el "bloque de constitucionalidad" por los arts. 93 y 214 No. 2 de la Constitución colombiana de 1991, tal como lo decidió la Corte Constitucional en su sentencia del 18 de mayo de $1995 .^{51}$ Este "bloque de constitucionalidad" está formado por los tratados de derechos humanos, las normas convencionales y consuetudinarias que forman el DIH y el resto del texto constitucional. ${ }^{52}$ La sentencia de la Corte corresponde la revisión constitucional del protocolo adicional II y de su ley aprobatoria (Ley 171 del 16 de diciembre de 1994) y aquí

\footnotetext{
${ }^{50}$ Krieger, Deutschland im asymmetrischen Konflikt, Online-Beiträge zum Völker- und Verfassungsrecht Nr. 2/2010, pág. 10; Ramelli, Derecho Internacional Humanitario y estado de beligerancia, pág. 37; Libardo Botero, La estratagema terrorista, pág. 236.

${ }^{51}$ Corte Constitucional, sentencia C-225 de 1995; Ramelli, Derecho Internacional Humanitario y estado de beligerancia, pág. 101; Ferro H, Existencia de un Conflicto Armado Interno, pág. 19.

52 Corte Constitucional, sentencia C-225 de 1995 y sentencia C-291 de 2007; Ramelli, La Constitución Colombiana y el derecho internacional humanitario, pág. 396
} 
la Corte confirmó otra vez que el DIH se aplica en Colombia en todo caso. ${ }^{53}$ Como resultado esto significa que las normas convencionales, consuetudinarias así como los principios generales del DIH en Colombia tienen rango constitucional.

El artículo 93 I C.P. establece que "los tratados y convenios internacionales ratificados por el Congreso, que reconocen los derechos humanos y que prohíben su limitación en los estados de excepción, prevalecen en el orden interno", mientras que el artículo 93 II C.P. establece que la Constitución Política colombiana debe ser interpretada de conformidad con los tratados internacionales sobre derechos humanos ratificados por Colombia. El artículo 214 No. 2 establece que tampoco en estados de excepción los derechos humanos y las leyes fundamentales pueden ser suspendidos y en todo caso el DIH debe ser respetado. Sin embargo, como también critica Ramelli, en esta sentencia la Corte evadió el debate sobre la aplicabilidad del DIH en el conflicto colombiano, es decir, el tema de sí en Colombia existe o no un conflicto armado interno. ${ }^{54}$ La Corte sólamente analizó la constitucionalidad de las normas.

La definición de un grupo armado según el protocolo adicional II de Ginebra aparece en el ordenamiento interno colombiano en el artículo 3 I de la ley 782 de $2002 .{ }^{55}$ Así, en Colombia, el derecho internacional humanitario está incorporado en el ordenamiento jurídico interno y el DIH con el protocolo adicional II de Ginebra es aplicable, siempre y cuando la situación en el país cumpla con las condiciones necesarias. ${ }^{56}$ La Corte Constitucional al final ha confirmado esto repetidas veces en decisiones posteriores. ${ }^{57}$

Como la Corte explica en su sentencia C-291 de 2007, las normas que forman parte del bloque de constitucionalidad cumplen diversas funciones dentro del ordenamiento jurídico colombiano. Primero una función interpretativa, que sirve de parámetro guía en la

\footnotetext{
${ }^{53}$ Corte Constiucional, sentencia del 18 de mayo de 1995, sentencia No. C-225/95; Ramelli, La Constitución Colombiana y el derecho internacional humanitario, pág. 480/481.

54 Ramelli, La Constitución Colombiana y el derecho internacional humanitario, pág. 481.

55 "De conformidad con las normas del Derecho Internacional Humanitario, y para los efectos de la presente ley, se entiende por grupo armado al margen de la ley, aquel que, bajo la dirección de un mando responsable, ejerza sobre una parte del territorio un control tal que le permita realizar operaciones militares sostenidas y concertadas."

56 Gonzáles Mongui, Derecho Internacional Humanitario, pág. 26.

57 Corte Constitucional, sentencia C-991 de 2000.
} 
interpretación del contenido de las cláusulas constitucionales y en la identificación de las limitaciones admisibles a los derechos fundamentales y segundo una función integradora, que sirve para encontrar parámetros específicos de constitucionalidad en ausencia de disposiciones constitucionales expresas. ${ }^{58}$

\section{Existencia de un conflicto armado interno en Colombia}

En el año 2004 con la sentencia T-025 de 2004 la Corte Constitucional ha reconocido la existencia de un conflicto armado interno en Colombia. ${ }^{59}$ Sin embargo, el gobierno del expresidente Álvaro Uribe Vélez (2002-2010) siempre negó la existencia de esta situación. El protocolo adicional II, art. 1 de las Convenciones de Ginebra establece que los grupos armados tienen que "ejercer una autoridad de facto sobre un territorio determinado" (ut supra). Según Uribe, la recuperación de gran parte del territorio colombiano por el Estado en los últimos años y el ejercicio del control militar en estas regiones, impide el cumplimiento de esta condición, en consecuencia, en Colombia no existe un conflicto armado interno, si no, como él lo ha definido, una situación interna de "amenaza terrorista contra el Estado". 60

¿Pero la solución es tan fácil? En las ciencias sociales así como en las ciencias jurídicas hay muchos críticos de esta opinión.

Ya en el año 1992, el Defensor del Pueblo Colombiano, en su informe sobre la situación de Derechos Humanos en Colombia estableció que existía un conflicto armado interno en el sentido del artículo 3 común de las Convenciones de Ginebra. ${ }^{61}$

Para el politólogo colombiano Eduardo Pizarro Leongómez en Colombia existe un conflicto armado interno. Según su definición, conflictos armados internos "son el producto del enfrentamiento entre el Estado y grupos de oposición interna sin la participación de

\footnotetext{
${ }^{58}$ Corte Constitucional, sentencia C-291 de 2007.

${ }^{59}$ Corte Constitucional, sentencia T-025 de 2002; Corte Constitucional, sentencia C-291 de 2007; Ferro H, Existencia de un Conflicto Armado Interno, pág. 19.

${ }^{60}$ Ferro H, Existencia de un Conflicto Armado Interno, pág. 17.

${ }^{61}$ Ramelli, La Constitución Colombiana y el derecho internacional humanitario, pág. 479.
} 
otros Estados en uno u otro bando". ${ }^{2}$ Los grupos armados no estatales que están involucrados en este conflicto, sufrieron en los últimos años una "degradación terrorista". El criterio del territorio para Leongómez no entra en consideración, entonces en Colombia se habla de un "conflicto armado interno, irregular, prolongado, con raíces ideológicas, de baja intensidad". 63

Para el proyecto Correlates of War (COW) de la Universidad de Michigan, se puede hablar de un conflicto armado interno, cuando existen combates armados en el territorio de un Estado, que involucran al Estado y a otras fuerzas organizadas, y existen al menos mil muertos relacionados con estos combates, de los cuales mínimo un 5\% fue ocasionado por el actor armado más débil. ${ }^{64}$ Una definición similar de conflicto armado interno plantea el proyecto de Uppsala-PRIO ${ }^{65}$, que habla de un conflicto armado interno cuando existen al menos 25 muertes por año relacionadas con enfrentamientos armados en el territorio de un Estado, en donde uno de los actores es el Estado. Ese conflicto debe ser llamado guerra cuando las muertes asociadas a los combates superan mil al año. ${ }^{66}$

Aunque estas intenciones de definir una situación de violencia interna con estadísticas de muertos por año parecen bastante arbitrarias, según estas conceptualizaciones, en Colombia existe desde hace muchos años un conflicto armado interno. ${ }^{67}$ Según el Informe anual de la Alta Comisionada de las Naciones Unidas para los Derechos Humanos en Colombia, que también establece que en éste territorio aún existe un conflicto armado interno, en 2011 hubo 1550 incidentes por minas anti personas, 5000 desplazados por acciones de las FARC-EP y varias muertos civiles relacionados con el conflicto armado, entre ellos 79 indígenas. $^{68}$

\footnotetext{
${ }_{63}^{62}$ Pizarro Leongómez, Una democracia asediada, pág 39.

${ }^{63}$ Ibíd, pág 80.

${ }^{64}$ Uprimny, ¿Existe o no Conflicto Armado en Colombia?, pág. 5; Pizarro Leongómez, Una democracia asediada, pág. 57; David Singer y Melvin Small, Correlates of War Project: International an Civil War Data, 1816-1992, 1994.

65 Proyecto conjunto desarrollado entre el Departamento sobre Paz y Conflicto de la Universidad de Uppsala y el Programa sobre las Condiciones de la Paz y la Guerra del Instituto Internacional para la Investigación sobre la Paz (PRIO) de Oslo (www.prio.no)

${ }^{66}$ Uprimny, ¿Existe o no Conflicto Armado en Colombia?, pág. 5; Pizarro Leongómez, Una democracia asediada, pág. 58.

${ }_{67}^{6}$ Uprimny, ¿Existe o no Conflicto Armado en Colombia?, pág. 5.

68 Informe de la ONU sobre la situación de derechos humanos en Colombia, 2011.
} 
El gobierno de Juan Manuel Santos determinó que en Colombia existe un conflicto armado interno. Es muy probable que esta decisión resulte principalmente del hecho, de que sin el reconocimiento del conflicto armado, Colombia no puede fácilmente luchar contra la guerrilla en el campo (por ejemplo con bombardeos). Esto explicó el presidente Santos en mayo 2011 en noticias Caracol. $^{69}$

Según Uprimny también existe un conflicto armado interno. El explica en un breve análisis de la situación en Colombia, que ésta cumple con todas las condiciones para la existencia de un conflicto armado interno según el protocolo adicional II. de las Convenciones de Ginebra $^{70}$ Así mismo afirmó, que el reconocimiento de este conflicto no debe ser confundido con la legitimación de las acciones de los grupos armados ilegales, ni con el apoyo al uso de la violencia. Entonces, sería necesario "reconocer la guerra para construir la paz". ${ }^{71}$

¿Cómo definir la situación en Colombia según el DIH? Se analizará entonces la situación colombiana según la definición del protocolo adicional II, el cual tiene las condiciones más estrictas. Si según el protocolo existe un conflicto armado en Colombia, también existe un conflicto armado en el sentido del artículo 3 común.

El análisis se concentrará en el grupo guerrillero, hoy en día, más grande en Colombia: las FARC-EP, con el cual muy probablemente podría lograr el estatus de grupo armado en un conflicto armado interno.

a) Participación de las fuerzas armadas regulares en el conflicto

Cumpliendo la primera condición, las Fuerzas Armadas regulares están involucradas en el conflicto colombiano. ${ }^{72}$ Los grupos armados al margen de ley involucrados son, por citar los más importantes hoy en día, las FARC-EP y el ELN. ${ }^{73}$

\footnotetext{
${ }^{69}$ Caracol Noticias, mayo 2011.

${ }^{70}$ Uprimny, ¿Existe o no Conflicto Armado en Colombia?, pág. 7.

${ }^{71}$ Uprimny, ¿Existe o no Conflicto Armado en Colombia?, pág. 8; similar Luis Carlos Restrepo Ramírez en Libardo Botero; La estratagema terrorista, pág 145.

72 Bolaños Enriquez, El derecho internacional humanitario ante los conflictos modernos, pág. 46; Informe de la ONU sobre la situación de derechos humanos en Colombia, 2011.
} 
b) Territorio

En el año 1998, el presidente Andrés Pastrana decidió remover las Fuerzas Armadas regulares de la región de San Vicente del Caguán en el sur de Colombia e instalar una zona desmilitarizada (zona de distensión). Esta fue la condición que impusieron las FARC-EP para un nuevo diálogo de paz. En dicho territorio, la guerrilla ejerció una autoridad de facto, en una zona que tuvo una gran dimensión, incluso superior al territorio de Suiza ${ }^{74}$, que según las definiciones expuestas con anterioridad, sería suficiente para cumplir la condición del "territorio". No obstante después del fracaso del dialogo con la guerrilla, en febrero de 2002, las Fuerzas Armadas ocuparon esta zona de nuevo. También en otras regiones del país por muchos años las FARC-EP han teniendo una presencia que les permitió realizar acciones militares concertadas. ${ }^{75}$

¿Cómo es la situación hoy en día? ¿Los grupos armados ilegales en Colombia todavía tienen un control suficiente en el sentido del protocolo adicional II?

Para Pizarro Leongómez las FARC tuvieron esta forma de control durante el tiempo de la "zona de distensión" pero hoy en día, gracias a la recuperación de grandes partes del territorio por parte el ejército nacional, la situación es diferente y no existe tal control. ${ }^{76}$ Los grupos armados ilegales en Colombia estarían lejos de tener una autoridad absoluta de facto sobre partes del territorio colombiano. ${ }^{77}$

Uprimny al contrario, dice que todavía las FARC tienen tal control sobre partes del territorio, porque aún se realizan acciones militares organizadas y durante años han tenido secuestrados a muchas personas que las Fuerzas Militares o la policía no han podido liberar fácilmente. ${ }^{78}$ En 2011, el conflicto armado interno se ha intensificado en los departamentos de Antioquia, Arauca, Caquetá, Cauca, Chocó, Meta, Nariño, Putumayo y Valle del Cauca

\footnotetext{
73 Ibid., pág 46.

${ }_{75}^{74}$ Pizarro Leongómez, Una democracia asediada, pág 63.

${ }^{75}$ Uprimny, ¿Existe o no Conflicto Armado en Colombia?, pág. 7.

${ }^{76}$ Pizarro Leongómez, Las Farc y el reconocimiento de beligerancia, El Tiempo, 2011.

${ }_{77}^{77}$ Pizarro Leongómez, Las Farc y el reconocimiento de beligerancia, El Tiempo, 2011.

${ }^{78}$ Uprimny, Sobre el conflicto armado en Colombia.
} 
por confrontaciones de la guerrilla con las Fuerzas Armadas regulares. ${ }^{79}$ Las FARC no obstante, ejercen un "control" sobre partes del territorio del Estado colombiano en el sentido del protocolo adicional II que les permite realizar acciones militares concertados.

c) Mando responsable

Las FARC tiene una estructura y organización militar bajo el mando de un comandante, que desde Noviembre de 2011 es Rodrigo Londoño Echeverri (alias Timoleón Jiménez o Timochenko). Según Pizarro Leongómez, "la máxima instancia decisoria de las FARC son las Conferencias Nacionales de Guerrilleros, las cuales designan al Estado Mayor Central y éste, a su turno, al Secretariado Nacional", ${ }^{80}$

La estructura del ELN es muy parecida, con un Comando Central y varias "Frentes de Guerra” en diferentes regiones de Colombia.

Esta estructura jerárquica como una comandancia superior es una estructura militar suficiente para cumplir la condición del mando responsable. ${ }^{81}$

d) Capacidad para aplicar el DIH

Según Pizarro Leongómez las FARC hoy en día no cumplen con esta condición, ya que así como no respetan de ninguna manera el DIH y tampoco lo aplican. ${ }^{82}$ Las FARC persisten en la comisión de crímenes de guerra (asesinato fuera de combate, uso de armas no convencionales) y crímenes de lesa humanidad (secuestro, toma de rehenes, reclutamiento de niños, niñas y adolescentes, minas anti-personas, etc.) y utilizan métodos y medios terroristas (bombas, atentados) dentro el marco del conflicto armado interno. ${ }^{83}$ Por lo tanto esta condición no será cumplida.

\footnotetext{
${ }^{79}$ Informe de la ONU sobre la situación de derechos humanos en Colombia, 2011.

${ }^{80}$ Pizarro Leongómez, Las Farc y el reconocimiento de beligerancia, El Tiempo, 2011.

${ }^{81}$ Uprimny, Sobre el conflicto armado en Colombia; Uprimny, ¿Existe o no Conflicto Armado en Colombia?, pág. 7; Bolaños Enriquez, El derecho internacional humanitario ante los conflictos modernos, pág. 47. Pizarro Leongómez, Las Farc y el reconocimiento de beligerancia, El Tiempo, 2011.

${ }^{82}$ Pizarro Leongómez, Las Farc y el reconocimiento de beligerancia, El Tiempo, 2011.

${ }^{83}$ Bolaños Enriquez, El derecho internacional humanitario ante los conflictos modernos, pág. 48; Pizarro Leongómez, Las Farc y el reconocimiento de beligerancia, El Tiempo, 2011; Informe de la ONU sobre la situación de derechos humanos en Colombia, 2011.
} 
Por otro lado Uprimny establece que las FARC tienen la "capacidad" para aplicar las normas del DIH, es decir, con su mando responsable y su organización militar las guerrilleros pueden lograr que los todos los sus miembros aplican el DIH. Esto sería suficiente para cumplir esta condición. ${ }^{84}$

Uprimny con su opinión tiene razon, teniendo en cuenta que el DIH obliga a la protección de la población civil. Si una parte involucrada en el conflicto no aplica las normas del DIH (lo cual puede ser común en conflictos en los que participan grupos armados ilegales), la población civil carecería de toda protección, en virtud de que estos grupo podrían bloquear el reconocimiento como conflicto armado interno ejerciendo acciones en contra el DIH. Esta situación estaría en contra del objetivo del protocolo adicional II. En cambio, si el conflicto está reconocido como conflicto armado interno, la consecuencia sería que los grupos involucrados ejercieran una verdadera capacidad para aplicar y respetar las normas del protocolo.

Para el Comité Internacional de la Cruz Roja en el Informe de actividades de 2004, en Colombia si existe un conflicto armado interno. Cabe anotar además, que la eventual existencia de actos prohibidos por el DIH no modifica la calificación jurídica del conflicto. ${ }^{85}$ Con el control sobre un territorio y un mando responsable, las FARC tienen la capacidad para aplicar las normas del DIH, sin importar las efectivas infracciones del DIH en Colombia. ${ }^{86}$

En conclusión, en Colombia están cumplidas todas las condiciones de la definición del protocolo adicional II y como vimos en el anterior aparte, según la opinión mayoritaria de las posiciones en el ámbito de las ciencias sociales y jurídicas, Colombia enfrenta un conflicto armado interno.

Sin embargo, la opinión más importante en contra de la existencia de un conflicto armado colombiano es la del ex-presidente Uribe. Pero su perspectiva no se sustenta en cuestiones

\footnotetext{
${ }^{84}$ Uprimny, ¿Existe o no Conflicto Armado en Colombia?, pág. 7.

${ }^{85}$ Libardo Botero, La estratagema terroristica, pág. 235.

${ }^{86}$ Uprimny, ¿Existe o no Conflicto Armado en Colombia?, pág. 7.
} 
legales sino en razones políticas. Ello se refleja cuando dice: "No se puede reconocer en la oposición armada la calidad de combatiente cuando su principal fuente de financiación es la droga y su segunda fuente es la más repugnante conducta contra la libertad humana: el secuestro". 87

Es verdad que los grupos armado ilegales en Colombia están involucrados en el narcotráfico y especialmente las FARC que hasta febrero de 2012 se ha financiado también con el dinero obtenido por el pago de rescates de los secuestrados. Sin embargo, esto es diferente y nada tiene que ver con la definición objetiva de la situación según el DIH. Las consideraciones de Uribe no deben ser valoradas dentro de una reflexión objetiva jurídica del caso. Jurídicamente es posible la afirmación de la existencia de un conflicto armado interno colombiano en el sentido del protocolo adicional II (y en consecuencia también del artículo 3 común) de las cuatro Convenciones de Ginebra.

\footnotetext{
${ }^{87}$ Ferro H, Existencia de un Conflicto Armado Interno, pág. 15; Uribe en: Libardo Botero, La estratagema
} terrorista, pág. 27. 


\section{Capítulo B. El Estado de Beligerancia}

\section{El reconocimiento de la beligerancia en el DIH}

El instrumento del reconocimiento de un grupo armado organizado como grupo beligerante no tiene ninguna fuente escrita en el derecho internacional público, sino más bien es un instrumento del derecho internacional consuetudinario.

La "beligerancia" y su reconocimiento tiene su origen moderno en la Guerra de Secesión americana en el año 1861 cuando Francia y el Reino Unido reconocieron a los confederados sureños como beligerantes. ${ }^{88}$ En el siglo XIX la comunidad internacional de esa época comenzó a establecer reglas para las partes en conflicto, con la intención de "humanizar la guerra" y dar a los combatientes un estatus jurídico definido (ver también las Convenciones de La Haya de los años 1899 y 1907).

Sobre la beligerancia en esa época, habían ya distintos puntos de vista sobre la cuestión, si el reconocimiento de la beligerancia sería un instrumento político o solamente una figura jurídica. Mientras que para los Estados Unidos era el instrumento del reconocimiento como objeto político, en el Reino Unido se trataba como instrumento únicamente jurídico. ${ }^{89}$

Como resume Ramelli, la beligerancia es un objeto político con efectos jurídicos. Político, porque en el acto del reconocimiento como beligerante se manifiesta la voluntad de un Estado de aceptar la existencia de una situación política dentro el territorio de un Estado. Jurídico, porque este reconocimiento acarrea unos importantes efectos jurídicos para las partes afectadas, como se verá a continuación. ${ }^{90}$

Vale aclarar que el estado de beligerancia y el estatus como grupo armado en un conflicto armado interno no debe ser confundidos como lo valoró el asesor presidencial de Colombia José Obdulio Gaviria hace algunos meses cuando afirmó:

\footnotetext{
${ }^{88}$ Ramelli, Derecho Internacional Humanitario y estado de beligerancia, pág. 18.

${ }^{89}$ Ibíd, pág. 19.

${ }^{90}$ Ibíd, pág 21.
} 
"Las FARC, es evidente, no controlan un territorio en el que tengan constituido un embrión de Estado, un principio de organización con los atributos de un gobierno, ejercido, aunque sea de una manera rústica y primitiva por un mando unificado. Si tuvieran control territorial, si una porción de la población colombiana, aunque fuera ínfima, estuviese viviendo bajo un régimen político establecido por las FARC, no habría más remedio que reconocerles su carácter de Estado en gestación. En ese caso, tendríamos un conflicto armado interno y el gobierno no le quedaría alternativa distinta a aceptarlo."91

Aceptar la existencia de un conflicto armado interno no es tanto como reconocer el estado de beligerancia de un grupo en este conflicto: reconocer que existe un conflicto armado interno con un grupo armado no implica ningún estatus jurídico para los miembros de este grupo, mientras que el reconocimiento como beligerante si tiene efectos jurídicos. En el derecho internacional público existen cuatro formas de reconocimiento:

- El reconocimiento de un Estado, que implica el reconocimiento de la existencia de un Estado con su propio territorio, su pueblo y soberanía. Es el reconocimiento de una entidad jurídica. $^{92}$

- El reconocimiento de un gobierno, que es importante en los casos de gobiernos de facto, que no obtienen su poder gracias a elecciones democráticas, sino a insurgencias o guerras. Un ejemplo, es el caso de Libia en el año 2011, en el que los Estados reconocieron el gobierno de transición como el gobierno legítimo.

- La tercera forma es el reconocimiento de insurgencia, que significa "un paso previo al del reconocimiento de beligerancia". ${ }^{93}$ Este estatus significa que los insurgentes no pueden ser tratados como simples criminales sino como delincuentes políticos, lo que tiene efectos en el orden jurídico interno, por ejemplo en el derecho penal. La diferencia

\footnotetext{
${ }^{91}$ Valcárcel Torres, Beligerancia, Terrorismo y Conflicto Armado, Internacional Law, pág. 383.

${ }^{92}$ Valencia, El reconocimiento de beligerancia frente al conflicto armado con las FARC-EP, pág. 15.

${ }^{93}$ Ibíd., pág. 16.
} 
con la beligerancia es en este caso, que los insurgentes no tienen un estatus especial en el derecho internacional - solo tiene efectos en el orden jurídico interno. ${ }^{94}$

- La cuarta forma es el reconocimiento de la beligerancia. La institución de la beligerancia se define como una situación en que una fuerza instituida (por ejemplo un grupo armado organizado) está luchando en contra del gobierno oficial, que tiene el poder dentro el Estado. ${ }^{95}$ En el año de 1900 el Instituto de Derecho Internacional de Neufchâtel definió el reconocimiento de la beligerancia en su artículo 4 así:

"El reconocimiento de beligerancia es un acto mediante el cual, bien un Gobierno reconoce que el conflicto armado que se desarrolla en su territorio es una guerra sometida al conjunto de las leyes y costumbres de la guerra, bien un tercer Estado considera que este conflicto armado constituye una guerra frente a la cual permanecerá neutral". ${ }^{96}$

\section{Los efectos del reconocimiento de la beligerancia}

El reconocimiento de un grupo armado como beligerante tiene básicamente tres consecuencias:

1. La neutralidad de terceros, es decir, que en las relaciones entre las partes que combaten no deben intervenir terceros Estados.

2. El Estado que ha reconocido un grupo armado responsable no es responsable por los actos ilícitos cometidos por miembros de este grupo. Los responsables serán las autoridades que tienen el control de mando sobre los beligerantes. ${ }^{97}$

3. El tercer punto es interesante para este análisis. Es la pregunta de, si los beligerantes siguen siendo sometidos al orden penal interno del Estado en cual hay el conflicto. La beligerancia da a los insurgentes una personalidad jurídica internacional parcial y temporal.

\footnotetext{
${ }^{94}$ Ibíd., pág. 16.

${ }^{95}$ Ibíd., pág. 5.

${ }^{96}$ Cit. Ramelli, Derecho Internacional Humanitario y estado de beligerancia, pág. 22.

${ }^{97}$ Valcárcel Torres, Beligerancia, Terrorismo y Conflicto Armado, Internacional Law, pág. 371/372.
} 
Esta personalidad jurídica es parecida a la de un Estado regular que implica la capacidad de los beligerantes de ser destinatario de derechos (por ejemplo presentarse ante organizaciones y tribunales internacionales) y obligaciones (por ejemplo la prohibición de cometer crímenes de guerra) que aparecen recogidos en las normas convencionales y consuetudinarias del derecho internacional público. ${ }^{98}$ Es temporal, porque el estado desaparece en el momento en que las fuerzas armadas regulares derroten a los insurgentes, se firmen un acuerdo de paz con el que se termine el conflicto o los insurgentes sean reconocidos como un gobierno legítimo por terceras partes.

Por otro lado, las leyes y costumbres de la guerra les son aplicables a un grupo armado, pero sólo si son reconocidos como beligerantes. Guerrilleros capturados pueden acogerse a las Convenciones de Ginebra, y especialmente gozar las reglas aplicables a prisioneros de guerra del Convenio III de Ginebra de 1949 ("relativo al trato debido a los prisioneros de guerra"). ${ }^{99}$ Esto significa, que los insurgentes beligerantes están sometidos parcialmente al derecho penal interno del Estado, y también a las normas del derecho internacional (las convenciones de Ginebra y a normas aplicables de tribunales internacionales). ${ }^{100}$

El art. 119 del Convenio III de Ginebra establece, que "los prisioneros de guerra procesados por un crimen o un delito de derecho penal podrán ser retenidos hasta que finalice el proceso y, eventualmente, hasta que hayan cumplido la sentencia". Esto significa que los prisioneros de guerra (combatientes beligerantes) pueden ser juzgados por la justicia y el derecho penal interno del Estado captor, pero solamente por delitos en los cuales pueden incurrir los miembros de sus propias fuerzas armadas regulares (art. 84 del Convenio III $^{101}$ ).

${ }^{98}$ Valencia, El reconocimiento de beligerancia frente al conflicto armado con las FARC-EP, pág. 29; Herdegen, Völkerrecht, § 7.

99 Ramelli, Derecho Internacional Humanitario y estado de beligerancia, pág. 29.

${ }^{100}$ Valcárcel Torres, Beligerancia, Terrorismo y Conflicto Armado, Internacional Law, pág. 371; Ramelli, Derecho Internacional Humanitario y estado de beligerancia, pág. 28.

${ }^{101}$ Art. 84 del Convenio III de Ginebra: Unicamente los tribunales militares podrán juzgar a un prisionero de guerra, a no ser que en la legislación de la Potencia detenedora se autorice expresamente que los tribunales civiles juzguen a un miembro de las fuerzas armadas de dicha Potencia por una infracción similar a la causante de la acusación contra el prisionero.

En ningún caso se hará comparecer a un prisionero de guerra ante un tribunal, sea cual fuere, si no ofrece las garantías esenciales de independencia y de imparcialidad generalmente reconocidas y, en particular, si su procedimiento no garantiza al acusado los derechos y los medios de defensa previstos en el artículo 105 . 
Aquellos delitos por los cuales los miembros de las fuerzas armadas regulares no pueden ser condenados, tampoco pueden ser objeto de un proceso penal en contra de miembros capturados de grupos beligerantes reconocidos.

En resumen, si un grupo está reconocido como beligerante, a los combatientes se les aplica el Convenio sobre los prisioneros de guerra de Ginebra. Si el grupo solamente cumple con las condiciones de un grupo armado en un conflicto armado interno, entonces a los combatientes se les considera como criminales (políticos) y deben ser juzgados de acuerdo con el derecho penal nacional.

\section{III. ¿Cómo se define un grupo beligerante?}

En el año 1952 Hans Kelsen determinó las condiciones para que los insurgentes sean reconocidos como grupo beligerante en la manera siguiente:

1. Los insurgentes deben tener un gobierno y una organización militar propia.

2. La insurrección debe ser conducida en forma técnica de guerra, es decir, debe ser algo más que una pequeña revuelta y asumir las verdaderas características de una guerra, especialmente considerando los medios de destrucción usados por las partes.

3. El gobierno de los insurgentes debe dominar efectivamente una cierta parte del territorio del Estado en el cual tiene lugar la guerra civil, es decir, el orden establecido por los insurgentes debe ser efectivo en cierta parte del territorio de este Estado. ${ }^{102}$

La definición de Juan José Quintana del año 1900 es parecida. Para él las condiciones de la beligerancia son:

1. El grupo debe tener una organización y mando, en el sentido de que opere bajo un esquema de autoridad jerárquica en el que se reconozca una cadena de mando y unas autoridades responsables por las acciones del grupo.

2. El grupo debe controlar por lo menos una porción de territorio del Estado donde tiene lugar el conflicto. Se entiende que el control debe ser permanente

\footnotetext{
${ }^{102}$ Kelsen, Principios de Derecho Internacional Público, 251.
} 
y público y debe haber sido logrado por las armas, es decir, el territorio de que se trate deberá haber sido arrebatado al gobierno como resultado de una acción o una serie de acciones bélicas.

3. El grupo debe respetar las normas esenciales del Derecho Internacional Humanitario. ${ }^{103}$

Así mismo, el Instituto del Derecho Internacional con la resolución del año 1900 y de acuerdo con Marco Gerardo Monroy Cabra los beligerantes deben controlar un gran parte del territorio del Estado sobre el cual se ejerce un cierto grado de control, sin olvidar que deben respetar las normas y usos de la guerra. ${ }^{104}$

Los requisitos expuestos parecen ser similares a la definición de un grupo armado en un conflicto armado interno (ut supra) se puede entonces aplicar como vigente:

- La existencia de un grupo armado ilegal bajo el control de un mando responsable.

- Que alguna parte del territorio del Estado se encuentre bajo el control del grupo armado, es decir, que ese grupo ejerza la autoridad civil, política y militar en este territorio.

- Y que el grupo armado organizado sea capaz de aplicar las normas del DIH. ${ }^{105}$

También podemos establecer, que el grupo armado ilegal tiene que luchar contra el Estado con el fin de remplazar al gobierno actual, es decir, los insurgentes tienen que tener fines políticos. Una lucha contra el Estado solamente por razones de criminalidad organizada no es suficiente.

Queda entonces, resolver la pregunta de si, cumpliendo estas condiciones, el grupo es reconocido como beligerante automáticamente?

En este punto hay que diferenciar entre la visión subjetiva y la visión objetiva del reconocimiento de la beligerancia. Los defensores de la visión subjetiva establecen que el

103 Quintana, Derecho Internacional Público Contemporáneo, pág 65; Valcárcel Torres, Beligerancia, Terrorismo y Conflicto Armado, Internacional Law, pág. 369/370.

${ }^{104}$ Valcárcel Torres, Beligerancia, Terrorismo y Conflicto Armado, Internacional Law, pág. 370; Ramelli, Derecho Internacional Humanitario y estado de beligerancia, pág. 26.

${ }^{105}$ Valcárcel Torres, Beligerancia, Terrorismo y Conflicto Armado, Internacional Law, pág. 370. 
acto del reconocimiento tiene un carácter constitutivo. Solamente si existe un reconocimiento oficial por parte de terceros, el grupo armado gozará de los efectos jurídicos de la beligerancia como estableció el Instituto de Derecho Internacional en el año 1900. ${ }^{106}$ Del mismo modo, Valcárcel Torres estableció en su tesis que la beligerancia a diferencia de la existencia de un conflicto armado, no es un estado ipso iure, sino que el reconocimiento tiene un carácter constitutivo y debe ser reconocido por otros sujetos del derecho internacional público; estos son hoy en día el gobierno legal del país afectado y terceros Estados. ${ }^{107}$

Por otro lado, para los defensores de la visión objetiva el reconocimiento de la beligerancia no tiene un carácter constitutivo sino el estatus se aplica ipso iure una vez las condiciones estén cumplidas. De esa manera lo decidió por ejemplo el Corte Suprema de los Estados Unidos en el contexto de la Guerra de Secesión en el año $1862 .{ }^{108} \mathrm{El}$ argumento más fuerte para la visión objetiva es, que los Estados afectados, lógicamente, no quieren reconocer la beligerancia de un grupo armado, ya que el estado de beligerancia, al contrario del reconocimiento de un conflicto armado (ut supra) tiene efectos jurídicos y políticos para este grupo. El reconocimiento como beligerante da una forma de "legitimidad" a los insurgentes y es claro que este reconocimiento daría como resultado un debilitamiento del gobierno legítimo y de la propia unidad nacional del Estado.

Consideramos que la visión subjetiva, según la cual el reconocimiento de la beligerancia tiene carácter constitutivo es válida. Los beligerantes gozan de un estatus jurídico en el derecho internacional. Este estatus solamente tiene sentido cuándo está reconocido por la comunidad de los otros Estados. Si los beligerantes deben cumplir únicamente con las condiciones necesarias, podría conducir a una inseguridad jurídica, pues podrían existir diferentes interpretaciones, acerca de si el grupo armado está cumpliendo o no las condiciones. Si existe un claro reconocimiento no hay dudas en el derecho internacional público que los efectos jurídicos se aplican o no.

\footnotetext{
${ }^{106}$ Ramelli, Derecho Internacional Humanitario y estado de beligerancia, pág. 26.

${ }^{107}$ Valencia, El reconocimiento de beligerancia frente al conflicto armado con las FARC-EP, pág. 22, 23.

${ }^{108}$ Ramelli, Derecho Internacional Humanitario y estado de beligerancia, pág. 26.
} 
Para efectos de esta investigación, el reconocimiento de beligerancia es una combinación entre la visión subjetiva y la visión objetiva. Las condiciones deben ser cumplidas para que sea claro internacionalmente cuando un grupo armado puede ser reconocido como beligerante, pero además necesita el reconocimiento oficial por el Estado propio o por parte de terceros. Como se estableció anteriormente, el conflicto armado (que no implica un cambio en el estatus jurídico de las partes) existe ipso jure y para hacer parte en este conflicto no es necesario que el grupo armado haya sido previamente reconocido como beligerante, sino que si las condiciones jurídicas sean cumplidas. ${ }^{109}$ Pero por otro lado, para que sea reconocido como beligerante debe existir un conflicto armado.

Lo más importante es el reconocimiento por el propio Estado que puede aceptar la beligerancia una vez las condiciones sean cumplidas por los insurgentes. Un tercer Estado solamente puede reconocer la beligerancia, sin el reconocimiento por el propio Estado, cuando el tercer Estado de alguna manera es afectado por el conflicto, ${ }^{110}$ por ejemplo, cuando los insurgentes tienen el control sobre un territorio en donde viven ciudadanos del tercer Estado. ${ }^{111}$

La declaración del reconocimiento por el gobierno del propio Estado puede ser expresa o concluyente (por ejemplo un intercambio humanitario de prisioneros, el intercambio de personal diplomático o acuerdos oficiales entre las partes). ${ }^{112}$ De otro lado el reconocimiento de beligerancia por parte de terceros siempre debe ser explicito. ${ }^{113}$ En la historia los casos en que un Estado ha reconocido formalmente la beligerancia de un grupo armado son pocos. Ejemplos son Francia y el Reino Unido a los confederados sudistas en la Guerra de Secesión en el año 1861 o el gobierno de Perú que en el año 1869 reconoció la beligerancia de los insurgentes que combatían contra los españoles por la independencia de Cuba. $^{114}$

\footnotetext{
109 pág. 3, 8 .

${ }^{110}$ Ibid, pág. 22.

${ }^{111}$ Herdegen, Völkerrecht, § 12, Rn. 2.

${ }^{112}$ Ramelli, Derecho Internacional Humanitario y estado de beligerancia, pág. 25, 43.

${ }^{113}$ Valencia, El reconocimiento de beligerancia frente al conflicto armado con las FARC-EP, pág. 22.

${ }^{114}$ Ramelli, Derecho Internacional Humanitario y estado de beligerancia, pág. 24.
} 
Antes el reconocimiento de la beligerancia era la única posibilidad para dar la protección de las normas del DIH a los combatientes. Herdegen asume que hoy en día el reconocimiento de la beligerancia no tiene tanta importancia, ya que también sin este reconocimiento existe un estándar mínimo para las víctimas de conflictos armados internos de acuerdo con el artículo 3 común de las Convenciones de Ginebra. ${ }^{115}$ Esta opinión es acertada desde el punto de vista de la protección del DIH, sin embargo, todavía el reconocimiento de la beligerancia es importante, pues esta condición tiene unos efectos jurídicos relevantes.

\section{IV. ¿Los grupos armados ilegales en Colombia deberían tener el estatus de beligerancia?}

En el año 1993 Valencia Villa afirmó que, desde los años 80s los grupos guerrilleros en Colombia representaron sujetos pasivos de una insurrección o beligerancia de facto $^{116}$, es decir la beligerancia nunca fue reconocida por terceros.

En el año 2008 el presidente de la República Bolivariana de Venezuela, Hugo Chávez, reconoció a las FARC-EP y al ELN como "insurgentes" y dijo que Colombia tenía que reconocer el estado de beligerancia de estos grupos guerrilleros pues estos grupos ocuparon un espacio en el territorio colombiano. Además, dijo que los países Europeos tenían que retirar los grupos guerrilleros (FARC y ELN) de la lista de grupos terroristas del mundo. ${ }^{117}$

También, en ese sentido, el presidente de Ecuador Rafael Correa en el año 2008 manifestó lo siguiente:

"Ecuador reconocería beligerancia de las FARC bajo ciertas condiciones[...]

Si las FARC cumplen con las condiciones para ser tratadas como una fuerza beligerante, que controle un territorio, que tenga una fuerza armada organizada, que respete los códigos de guerra, los tratados de Ginebra, etc., por supuesto que tendríamos que reconocerla como fuerza beligerante. Para

\footnotetext{
${ }^{115}$ Herdegen, Völkerrecht, $\S 12$, Rn. 3.

${ }^{116}$ Ramelli, Derecho Internacional Humanitario y estado de beligerancia, pág. 34.

117 Valencia, El reconocimiento de beligerancia frente al conflicto armado con las FARC-EP, pág. 3; "Presidente Uribe, si usted le reconoce a las Farc estado de beligerancia y aceptan, entrarían de inmediato en los protocolos de Ginebra (...) Y para que una fuerza insurgente sea beligerante, sea reconocida, debe renunciar al secuestro, a los actos terroristas contra la población civil”, El Tiempo, 14 de enero de 2008.
} 
alcanzar este estatus tendrían que renunciar a prácticas como secuestros, atentados, etc."118

El gobierno Colombiano ha protestado contra la insistencia del reconocimiento de la beligerancia de las FARC por el gobierno ecuatoriano. Como dijo el ex-canciller colombiano Fernando Araújo, "un gobierno democrático no puede aparecer ahora interesado en conceder condición de beligerante a un grupo terrorista que hace tanto daño a Colombia y lo ha hecho durante tantos años; que ha secuestrado, que mantiene secuestrados, que hace atentados contra mujeres, niños y contra la infraestructura." ${ }^{\prime 19}$ En realidad ninguno de los grupos armados ilegales en Colombia (ELN, FARC,...) alguna vez ha sido reconocido expresamente como beligerante por el Estado Colombiano. Como se estableció más arriba, la beligerancia no es un estatus ipso jure sino sólo se aplica por reconocimiento oficial.

El Estado Colombiano nunca declaró expresamente un reconocimiento de beligerancia, ¿pero quizás lo hizo tácitamente (reconocimiento concluyente)? Dicho reconocimiento puede ser posible por medio de un intercambio de prisioneros, de personal diplomático o con acuerdos oficiales (ut supra). Durante los años 1997-2002 el gobierno Pastrana llevó a cabo un "dialogo de paz" oficial con las FARC (que resultó en una zona desmilitarizada temporal, ut supra). La pregunta es si este dialogo puede ser entendido como un reconocimiento tácito y, si el Estado tenía la voluntad de reconocer en este caso la beligerancia.

Un Estado debe declarar el reconocimiento de la beligerancia. Esta declaración puede ser expresa o concluyente pero nunca por descuido. En este orden de ideas, para que exista este reconocimiento, siempre es necesaria una voluntad clara. En el derecho penal colombiano los miembros de grupos guerrilleros que están condenados por crímenes no tienen ningún estatus especial, es decir, son tratados como criminales comunes y no como beligerantes.

\footnotetext{
${ }^{118}$ Colombia protestará ante Ecuador por insistencia en beligerancia de las FARC, El País, 2008; Valcárcel Torres, Beligerancia, Terrorismo y Conflicto Armado, Internacional Law, pág. 384.

${ }^{119}$ Colombia protestará ante Ecuador por insistencia en beligerancia de las FARC, El País, 2008.
} 
De eso podemos deducir de manera concluyente, que el Estado no ha tenido la voluntad de reconocer la beligerancia de las FARC u otros grupos armados ilegales, lo cual es un comportamiento contradictorio del Estado colombiano, pues el gobierno con este diálogo de la paz pareciera haber reconocido la beligerancia de este grupo, sin embargo, todavía se trata a los guerrilleros como simples criminales. Por la anterior, se puede afirmar que el Estado colombiano nunca ha reconocido expresa ni concluyentemente la beligerancia de ningún grupo armado ilegal en su territorio.

Además, como Valcárcel Torres en el año 2008 ha establecido, que hoy en día los grupos armados ilegales en Colombia no cumplen con las condiciones necesarias para ser reconocido como beligerante porque ellos no son autoridad civil, ni militar, ni política en ningún parte del territorio. ${ }^{120}$ En el capítulo A de esta tesis se estableció que los grupos armados ilegales colombianos ejercen un control sobre algunas partes del territorio, lo cual les permite realizar acciones militares organizadas, pero esto no significa, que en estos territorios ejerzan un verdadero control.

Para el reconocimiento como beligerante es necesario un verdadero control sobre el territorio. Por otra parte, los fines de un grupo beligerante deben ser políticos, es decir, que los insurgentes quieran reemplazar la autoridad pública del Estado. Para alcanzar este fin los beligerantes requieren el apoyo de gran parte de la población o por lo menos un gran poder militar. Así es, que en un punto determinado, los insurgentes deben tener un control tan fuerte sobre parte del territorio que les permita, alcanzar sus fines políticos y expulsar a la fuerza pública vigente del territorio del Estado. Sin la posibilidad de ejercer un control total sobre los territorios ganados, los insurgentes nunca podrían alcanzar el fin de controlar la totalidad del Estado. Por esto la condición del poder territorial es más estricta para el reconocimiento de la beligerancia, que para la de un conflicto armado.

Hoy en día la fuerza pública en Colombia oficialmente ejerce la autoridad en todo el país. Un control que solamente les permite, realizar acciones militares, como es la situación de los grupos armados ilegales en Colombia (ut supra), no es suficiente para cumplir la

\footnotetext{
${ }^{120}$ Valcárcel Torres, Beligerancia, Terrorismo y Conflicto Armado, Internacional Law, pág. 387.
} 
condición expuesta del territorio, y de allí obtener un reconocimiento como beligerante. Por lo tanto en el caso colombiano la condición del territorio no se cumple.

Además hay dudas acerca de si los grupos guerrilleros colombianos o los grupos paramilitares tienen fines políticos, sino que por el contrario, tienen fines criminales como la financiación por medio del tráfico de drogas o del secuestro. Como se dijo, los grupos beligerantes deben que tener fines políticos (ut supra). Claro está, que si bien en un tiempo los grupos guerrilleros en Colombia tuvieron ideales políticos, hoy en día, esto no es claro, se cree más bien que solamente se trata de criminalidad organizada. ¿Porque?

Ya en el año 2002 el gobierno nacional, con la dirección del Departamento Nacional de Planeación, estableció en el Plan Nacional de Desarrollo que el crecimiento de los cultivos ilícitos, especialmente de cocaína, "ha sido la principal causa de la expansión de los grupos al margen de la ley. [...] Las rentas originadas por los cultivos ilícitos han permitido el encarecimiento de personal y capacidad logística de los grupos violentos". ${ }^{121}$ También el Comisionado de Paz, Luis Carlos Restrepo en el año 2005 explicó que "No nos [el gobierno] interesa conceder estatus político a grupos armados al margen de la ley. No creemos pertinente que el Jefe del Estado [Uribe] reconozca como movimientos políticos a organizaciones que matan secuestran o delinquen". ${ }^{122}$

Como establece Pizarro Leongómez para saber si en Colombia los grupos armados ilegales todavía luchan con una ideología política, uno tiene que definir, si hoy en día el narcotráfico es la motivación final de los actores armados o si se trata de un simple combustible del conflicto, que es necesario para los grupos armados ilegales para financiarse. ${ }^{123}$ Para Pizarro Leongómez, el involucramiento de los grupos guerrilleros en la criminalidad común y el narcotráfico, es hoy en día un medio importante para financiar la guerra. Sin embargo, la guerrilla sigue luchando en primer lugar por sus fines políticos y

\footnotetext{
${ }^{121}$ Departamento Nacional de Planeación, Hacia un Estado comunitario, Plan Nacional de Desarrollo (20022006), pp. 15-16.

${ }^{122}$ Libardo Botero, Un esfuerzo honesto por corregir la historia, pág 22 en Libardo Botero, Crímenes altruistas.

${ }^{123}$ Ibíd, pág 169.
} 
solamente en segundo lugar por negocios ilícitos. Entonces el narcotráfico y la criminalidad común son combustibles del conflicto colombiano. ${ }^{124}$

La difícil situación es, que hoy en día los grupos guerrilleros tienen una mezcla de ideologías (marxista-leninista-bolivariana). Además, nadie sabe si la mayoría de los miembros de la guerrilla todavía están luchando por sus ideales políticos o más por razones criminales. Si nadie sabe esto, es difícil determinar si los grupos cumplen o no cumplen con la condición de una "lucha política" contra el Estado. También Ramelli estableció en el año 2004, que es "imposible afirmar de manera categórica que los grupos armados [colombianos] constituyen una comunidad beligerante o [...] gozan de capacidad jurídica internacional". ${ }^{125}$

Generalmente es muy difícil determinar, si la guerrilla todavía tiene fines políticos. Sin embargo, esta suposición no puede ser totalmente excluida. Probablemente hoy en día la guerrilla está siguiendo tanto intereses políticos como intereses económicos. Debido a que entre los miembros de la guerrilla, presumiblemente, existen muchas perspectivas y fines ideológicos diferentes, parece imposible determinar, cuales fines son los más importantes.

Aunque las pocas chances de la guerrilla de alcanzar sus fines políticos por medio de la lucha armada, los crímenes con gran rentabilidad como el narcotráfico generalmente pueden ser un factor que corrompe aun mas esos fines, sin embargo, al no haber claridad, tenemos que asumir, que los fines políticos todavía existen. De otra manera, atentados terroristas contra instituciones estatales, como en febrero de este año, contra la estación de la policía en Tumaco en el Departamento de Nariño, no pueden ser explicados.

No obstante, como ya se planteó, las otras condiciones (territorio, reconocimiento) tampoco están cumplidas.

Como conclusión, podemos establecer que esencialmente por dos razones no se puede asumir que algún grupo armado colombiano tiene el estatus de beligerancia. Primero,

\footnotetext{
${ }^{124}$ Pizarro Leongómez, Una democracia asediada, pág 201.

${ }^{125}$ Ramelli, Derecho Internacional Humanitario y estado de beligerancia, pág. 42.
} 
porque el gobierno colombiano u otro tercer estado nunca ha reconocido la beligerancia y esta es una condición necesaria; segundo, porque tampoco las condiciones materiales de la beligerancia están cumplidos por ningún grupo armado en Colombia. En conclusión, en Colombia no existen grupos beligerantes y pues los grupos armados al margen de la ley en Colombia no se cumplen con las condiciones de la beligerancia, tampoco deberían ser reconocidos como beligerantes.

La consecuencia de que los grupos armados en Colombia no estén reconocidos como beligerantes, es que los miembros de estos grupos que son capturados por el Estado no son prisioneros de guerra y pueden ser tratados como simples criminales. De la misma manera las personas secuestradas por la guerrilla tampoco son prisioneros de guerra, sino simplemente víctimas del crimen grave de toma de rehenes (art. 148 C.P) o del secuestro (art. 168 - 171 C.P.). Si los grupos armados ilegales fueran reconocidos como beligerantes, los miembros de estos grupos no estarían totalmente sometidos al derecho penal colombiano. Pero como no es el caso, en consecuencia el derecho penal colombiano es completamente aplicable a los miembros de los grupos armados ilegales colombianos.

En el capítulo siguiente analizará como el ordenamiento del derecho penal colombiano trata a los miembros de los grupos al margen de la ley en Colombia. 


\section{Capítulo C. ¿Pueden miembros de grupos no reconocidos como beligerantes ser tratados como delincuentes políticos?}

\section{Consideraciones generales}

Aún cuando se reconociera la existencia de un conflicto armado interno en el que el DIH sea aplicable, el Estado colombiano tiene la jurisdicción penal sobre los miembros de los grupos armados ilegales colombianos, sin importar, si existe un conflicto armado interno o no, porque este no tiene efectos para el estatus jurídico de las partes (ut supra).

Pero en el tratamiento según el ordenamiento penal interno colombiano también existen incertidumbres que se deben aclarar.

Al principio, es importante constatar que en Colombia el juzgamiento de civiles por parte de la justicia penal militar (artículo 213 C.P.) está prohibido. Este artículo aplica tanto el art. 8 de la Convención Americana sobre Derechos Humanos (CADH) como el art. 6 II del protocolo adicional II de Ginebra, que establecen que la justicia debe garantizar un juicio imparcial e independiente, establecido por la ley. ${ }^{126}$

\footnotetext{
${ }^{126}$ Art. 8 I CADH: Toda persona tiene derecho a ser oída, con las debidas garantías y dentro de un plazo razonable, por un juez o tribunal competente, independiente e imparcial, establecido con anterioridad por la ley, en la sustanciación de cualquier acusación penal formulada contra ella, o para la determinación de sus derechos y obligaciones de orden civil, laboral, fiscal o de cualquier otro carácter.

Art. 6 II protocolo adicional II: No se impondrá condena ni se ejecutará pena alguna respecto de una persona declarada culpable de una infracción, sino en virtud de sentencia de un tribunal q ue ofrezca las garantías esenciales de independencia e imparcialidad. En particular:

a) el procedimiento dispondrá que el acusado sea informado sin demora de los detalles de la infracción que se le atribuya y garantizará al acusado, en las actuaciones que procedan al juicio y en el curso de éste, todos los derechos y medios de defensa necesarios;

b) nadie podrá ser condenado por una infracción si no es sobre la base de su responsabilidad penal individual;

c) nadie será condenado por actos u omisiones que en el momento de cometerse no fueran delictivos según el derecho; tampoco se impondrá pena más grave que la aplicable en el momento de cometerse la infracción; si, con posterioridad a la comisión de la infracción, la ley dispusiera la imposición de una pena más leve, el delincuente se beneficiará de ello;

d) toda persona acusada de una infracción se presumirá inocente mientras no se pruebe su culpabilidad conforme a la ley;

e) toda persona acusada de una infracción tendrá derecho a hallarse presente al ser juzgada;

f) nadie podrá ser obligado a declarar contra sí mismo ni a confesarse culpable.
} 
Como los miembros de grupos armados ilegales en Colombia tienen la categoría de civiles, la justicia penal ordinaria es la única instancia que puede condenar a estas personas. Los jueces competentes para conocer de los delitos cometidos en relación con el conflicto armado interno, son los jueces penales especializados del circuito y para investigar y dado el caso ejercer la acción penal sus respectivos fiscales delegados. ${ }^{127}$ Estos delitos son por ejemplo terrorismo (art. 343 C.P.), rebelión (art. 467 C.P.), sedición (art. 468 C. P.), asonada (art. 469 C.P.) o cualquier formación o ingreso de personas a grupos armados, la instrucción y entrenamiento de ellos o también el ilícito de omisión de denuncia sobre actividades terroristas (art. 340 C.P. y siguiendo).

\section{La delimitación entre delito común y delito político}

\section{Definición y Delimitación}

En el derecho penal colombiano se conocen dos clases de delitos que no deben ser confundidos, los delitos políticos y los delitos comunes. ¿Cuál es la diferencia?

Ni la Constitución ni el Código Penal definen el término "delito político". ${ }^{128}$ El artículo 35 C.N. establece que la extradición no se procederá por delitos políticos y el artículo 179 C.N. dispone que personas que hayan sido condenados en cualquier época por sentencia judicial, a pena privativa de la libertad, excepto por delitos políticos o culposos y también el art. 150 No. 17 C.N. (indultos o amnistías) ordena un tratamiento diferente para delitos políticos y comunes.

No obstante, la Constitución no define que es un delito político o cual es el límite entre delitos políticos y no políticos. Sin embargo, en la doctrina jurídica tal como en la jurisprudencia existen criterios para definir esta clase de delitos. Pabón Parra entiende por delitos políticos, aquellos "que atentan contra el régimen de organización política y, en general, contra la seguridad, estabilidad y orden interior de la Nación" (objetivo) y que "se originan cuando los móviles que han determinado el hecho son nobles y altruistas,

\footnotetext{
${ }^{127}$ Ramelli, La Constitución colombiana y el Derecho Internacional Humanitario, pág. 529.

${ }^{128}$ Castro, Delitos contra el régimen constitucional y legal, pág. 165.
} 
generados por concepciones ideológicas sobre la forma de organización que debe asumir el Estado" (subjetivo). ${ }^{129}$ Según una definición más vaga, pero básicamente parecida, para Carlos Zarate los delitos políticos "asumen el carácter de políticos por virtud del motivo que haya determinado al delincuente en su acción y por la naturaleza del derecho lesionado". En el delito común los móviles son de interés egoísta y antisocial, en el delito político los motivos son de carácter social, noble o altruista. ${ }^{130}$

Por su parte, la Corte Constitucional ha establecido que "el delito político es aquel que, inspirado en un ideal de justicia, lleva a sus autores y copartícipes a actitudes prescritas del orden constitucional y legal, como medio para realizar el fin que se persigue". ${ }^{131}$ En igual sentido se ha manifestado la Sala de Casación Penal de la Corte Suprema de Justicia cuando sostuvo: "Haciendo un parangón entre el delito común y el delito político, por su aspecto subjetivo, se ha dicho que en el primero el agente realiza el hecho casi siempre por motivos innobles, o bajo el influjo de pasiones desbordadas, con perversidad, o con fines de venganza. Por el contrario, en el segundo, los móviles son casi siempre políticos o de interés común; la aspiración a lograr un replanteamiento de las condiciones económicas, políticas y sociales de una colectividad son - por regla general - los factores determinantes de esta clase de delincuentes". ${ }^{132}$ En tal sentido la misma Sala en el año 1995 sostuvo que "el delito común es aquella infracción penal cuya realización busca el cambio de las instituciones o sistemas de Gobierno para implantar otros que el sujeto activo, generalmente caracterizado por su espíritu altruista y generoso, considera más justo. Por tal razón, el motivo determinante de su realización ha de ser igualmente político."133

En resumen, como "delito político" se definen aquellos delitos que atentan contra el bien jurídico denominado régimen constitucional y legal. ${ }^{134}$ Son los delitos establecidos en los títulos XVII y XVIII del Código Penal como por ejemplo la rebelión (art. 467 C.P.), la sedición (art. 468 C.P.), la asonada (art. 469 C.P.) o la conspiración (art. 470 C.P.) y

\footnotetext{
${ }^{129}$ Pabón Parra, Manual del derecho penal, pág. 1437.

${ }^{130}$ Carlos Zárate, El delito político, pág. 153.

${ }^{131}$ Corte Constitucional, sentencia del 17 de enero de 1995.

${ }^{132}$ Corte Suprema de Justicia, sentencia del 26 de mayo de 1982.

${ }^{133}$ Corte Suprema de Justicia, sentencia del 7 de abril de 1995.

${ }^{134}$ Castro, Delitos contra el régimen constitucional y legal, pág. 166.
} 
además los delitos conexos con estas conductas. ${ }^{135}$ Debe afirmarse, que todas las acciones y opiniones contra el Estado, expresadas por mecanismos democráticos o por medios no violentos no constituyen delitos políticos. ${ }^{136}$

Por otra parte los delitos definidos como "delitos comunes" hacen referencia a todos los demás delitos establecidos en el Código Penal. ¿Pero qué pasa entonces con los delitos, que normalmente significarían delitos comunes, pero que por las circunstancias están conectados con delitos políticos o que tienen un fondo político? La forma en que se ejecuta la represión penal de los miembros de grupos armados ilegales que cometieron delitos en el contexto del conflicto colombiano siempre ha sido muy discutida en Colombia, especialmente la categoría del "delito político". 137

En el ámbito del conflicto armado interno colombiano la distinción entre delito político y delito común no siempre es fácil. A pesar de que la doctrina y filosofía de los grupos guerrilleros manifiesta una lucha armada revolucionaria con raíces marxistas-leninistas, la constante realización de delitos comunes por estos grupos (como narcotráfico, secuestro, extorsión, etc.) y delitos terroristas, o actos de guerra, como los denominan los guerrilleros (atentados contra instituciones del Estado, voladura de oleoductos y torres de conducción de energía eléctrica) han conducido a un punto, en el que no se puede definir claramente cuáles son los delitos de carácter exclusivamente político y cuáles no. ${ }^{138}$

El ex-presidente Uribe en mayo del año 2005 ha planteado unas cuestiones en el debate la existencia del delito político en Colombia. El sostiene, que la idea de la existencia del delito político en una democracia carece de toda razón, pues "en una democracia profunda, no se acepta que las personas atenten contra esa democracia por razones ideológicas, por razones políticas, por la vía armada. Entonces, [...] no se acepta que un delito que este apoyado con armas, sea político. [...]Una democracia que así se profundiza, es una democracia que tiene que pensar si sí vale la pena darle el estatus de delincuente político a quien atentó contra ella, por la vía armada. Por eso yo creo, que ante una democracia profunda, debe pensarse

\footnotetext{
${ }^{135}$ Pabón Parra, Manual del derecho penal, pág. 1437.

${ }^{136}$ Castro, Delitos contra el régimen constitucional y legal, pág. 164.

${ }^{137}$ Ramelli, La Constitución colombiana y el Derecho Internacional Humanitario, pág. 530.

${ }^{138}$ Ibid, pág. 530.
} 
en no calificar como político el delito basado en armas, es simple terrorismo". ${ }^{139}$ Poner bombas o secuestrar ciudadanos no son actividades políticas en una democracia, por esto Uribe dijo, que el delito político no deberá existir en una democracia. Para él, cualquier atentado armado contra el orden del Estado es un caso de terrorismo que no debe ser tratado de manera preferente respeto a cualquier otro delito. ${ }^{140}$ En otras palabras, según Uribe, criminales no deben ser privilegiados solamente porque el delito sea cometido por razones “altruistas" o por el "interés común”, concordante con el argumento de la Corte Suprema de Justicia (ut supra). El delito político, sin embargo, es un acto en contra del orden del Estado y puede causar daño, también en la población civil y esto debe ser penalizado por ese Estado.

Cada Estado, que tiene en su legislación delitos políticos, tiene que preguntarse, si el tratamiento preferencial de personas, que luchan contra el mismo Estado, tiene sentido. ${ }^{141}$ No obstante, en Colombia todavía existe la categoría del delito político. Alrededor del delito político en el año 1997 se pronunció la Corte Constitucional frente a la difícil delimitación entre delitos políticos y comunes.

\section{Sentencia C-456/97 de la Corte Constitucional}

En el Código Penal anterior (decreto 100 de 1980) el legislador colombiano en el artículo 127 estableció la posibilidad de la extinción de la pena para "los rebeldes o sediciosos [...] por hechos punibles cometidos en combate, siempre que no constituyan actos de ferocidad, barbarie o terrorismo" (Titulo II, De los delitos contra el régimen constitucional, artículo 127). El sentido de esta norma buscaba resolver el dilema producido por la imprecisa delimitación entre delitos políticos y delitos comunes en el caso colombiano. Como resultado, todos los delitos comunes cometidos por miembros de grupos armados en combate, quedaban subsumidos bajo el termino delito político, salvo actos de "ferocidad, barbarie o terrorismo".

\footnotetext{
${ }^{139}$ Uribe, ¿Debe existir el delito político en Colombia?, 18 de mayo de 2005; también Libardo Botero, Un esfuerzo honesto por corregir la historia, en Libardo Botero, Crímenes altruistas, pp. 17.

${ }^{140}$ Entrevista de Uribe con El País de Cali, 2005 en Libardo Botero, Crímenes altruistas, pág. 62; también en el mismo libro, Libardo Botero, Un esfuerzo honesto por corregir la historia, pág 19.

${ }^{141}$ García Amado, Delito político, pág 14.
} 
Esta norma fue objeto de discusión en la jurisprudencia colombiana, mientras que la Sala Plena de la Corte Suprema de Justicia en su sentencia del 10 de febrero de 1983 declaró exequible el artículo 127 del Código Penal ${ }^{142}$, la Corte Constitucional en su sentencia del 23 de septiembre de 1997 (C-456/97) declaró inexequible esta norma. ${ }^{143}$ Vale aclarar, que la Corte Suprema basó su sentencia en la Constitución de 1886 y la Corte Constitucional en la nueva Constitución de 1991.

Los argumentos de la Corte Constitucional fueron, en primer lugar que la norma otorga una forma de amnistía "general, anticipada e intemporal" a los miembros de grupos armados ilegales por delitos comunes siempre cuando hayan sido cometidos en combate. ${ }^{144}$ También la Corte se refirió a los derechos humanos de los miembros de las Fuerzas Armadas cuando estableció que una norma penal que no castiga personas responsables por la muerte de miembros de las Fuerzas Armadas viola sus derechos fundamentales. ${ }^{145}$

Otro argumento de la Corte fue, que los valores de la Constitución de 1991 estaban amenazados por una norma penal que, como resultado, fomentaba el conflicto armado interno, como quiera que los combatientes ilegales eran instigados a la utilización de medios violentos para alcanzar sus fines, especialmente, porque la Constitución colombiana contiene medios de participación pacíficos para lograr cambios en el sistema político colombiano. ${ }^{146}$ Por lo cual, el legislador colombiano no puede promulgar una norma que como resultado debilite la unidad de la nación. Es un argumento que en general pone en duda la categoría del delito político.

También los magistrados establecieron que el artículo 127 mezcla delitos comunes (homicidio, hurto etc.) con delitos políticos (rebelión, sedición, etc.). Aunque las dos categorías a veces coinciden parcialmente, el legislador debe trazar una línea clara para delimitar las dos categorías en la doctrina penal.

\footnotetext{
${ }^{142}$ Corte Suprema de Justicia, sentencia del 10 de febrero 1983.

${ }^{143}$ Corte Constitucional, sentencia C-456/97.

${ }^{144}$ Ibíd, pág. 242.

${ }^{145}$ Ibíd, pág. 247.

${ }^{146}$ Ibíd, pág. 247.
} 
La mayoría de los magistrados de la Corte estuvieron de acuerdo con esta sentencia, pero, también se escucharon opiniones críticas que sostuvieron que esta conexidad de los delitos comunes con los delitos políticos "era una consecuencia de la complejidad fáctica que presenta el delito político", tal y como se venía asumiendo hasta antes de la sentencia de constitucionalidad. En un combate muchas veces es prácticamente imposible determinar responsabilidades individuales por delitos comunes cometidos. ${ }^{147}$

Además algunos de ellos establecieron en los salvamentos de votos, que el tratamiento punitivo preferencial de los delitos políticos era ordenado por la Constitución, por ejemplo en el ámbito de la no extradición. El artículo 127 del Código Penal se acomoda perfectamente al "espíritu” de la Constitución de $1991 .{ }^{148}$

Otra opinión manifestada en el salvamento de voto también critica, que si un guerrillero da de baja a un militar, se inicia contra él un proceso por homicidio, mientras que, por otro lado, un militar da de baja a un guerrillero, no se inicia acción penal alguna, teniendo como posible argumento que el ejercicio es la legítima defensa estatal y tiene con una de sus funciones la protección del orden constitucional. Para los autores del salvamiento de voto este resultado está en contra del DIH y de la propia Constitución. Se estableció también que la igualdad entre los combatientes (las fuerzas armadas legales y los grupos armados ilegales), "constituía un imperativo de la legalidad internacional". ${ }^{149}$

Ramelli afirma, que la sentencia, desde una perspectiva política es favorable para el proceso de paz en Colombia. El estableció que la sentencia reforzó la posición del gobierno, pues únicamente mediante las leyes de amnistía o por indultos los miembros de grupos armados ilegales podrían exonerarse de su responsabilidad penal, pero no por vía de una ley penal, que generalmente sea benévola para todos los miembros de grupos armados por delitos, cometidos en combate. $^{150}$

\footnotetext{
${ }^{147}$ Ramelli, La Constitución colombiana y el Derecho Internacional Humanitario, pág. 534.

148 Corte Constitucional, sentencia C-456/97, voto particular de los magistrados Carlos Gaviria Díaz y Alejandro Martínez, pág. 256 a 278; también Ramelli, La Constitución colombiana y el Derecho Internacional Humanitario, pág. 533.

${ }^{149}$ Ramelli, La Constitución colombiana y el Derecho Internacional Humanitario, pág. 535.

${ }^{150}$ Ramelli, La Constitución colombiana y el Derecho Internacional Humanitario, pág. 538.
} 
No obstante, como se ha establecido en el capítulo anterior, los grupos armados ilegales en Colombia no tienen ningún estatus jurídico especial, sino que están siendo tratados como criminales. Con el artículo 127 de Código Penal el legislador colombiano ignoró esto y otorgó a los guerrilleros un estatus jurídico especial de facto. Como resultado la guerrilla gozaba de un estatus distinto a los criminales "normales", salvo por los actos cometidos con "ferocidad, barbarie y terrorismo". La actuación del legislador colombiano era entonces contradictoria, pues por un lado, no quería otorgar un estatus especial a los miembros de los grupos armados ilegales y por otro lado, éstas personas estaban siendo tratadas preferentemente por el derecho penal. En este sentido la sentencia de la Corte Constitucional genera seguridad jurídica, ya que ha aclarado que los guerrilleros no pueden gozar un tratamiento benévolo por ser "simples" criminales.

Como resultado, este fallo significa que hoy en día los delitos políticos y los delitos comunes cometidos por la guerrilla en el derecho penal están separados y que delitos comunes no deben ser subsumidos por delitos políticos. Miembros de grupos armados ilegales generalmente pueden ser condenados por ambas categorías de delitos cometidos en combates.

\section{Las infracciones al DIH en el orden del derecho penal colombiano frente al conflicto colombiano}

Aunque las cuatro Convenciones de Ginebra en sus artículos 49, 50, 129 y 146 (respectivamente del Convenio I, II, III y IV) contienen la obligación de los Estados de establecer normas en su legislación penal interna que penalizan infracciones al DIH. Sin embargo, estas normas solamente se aplican a situaciones de conflictos armados internacionales y no a conflictos armados internos, como en el caso colombiano.

El artículo 3 común y el protocolo adicional II de las Convenciones de Ginebra contienen una lista de comportamientos prohibidos, pero los Estados no están obligados a penalizarlos. Sin embargo, las conductas delictivas en el DIH no están descritas con suficiente claridad, por ejemplo el DIH no establece nada sobre la pena por 
comportamientos delictivos. ${ }^{151}$ Es decir, que es la obligación de los Estados, establecer y delimitar las conductas y las penas en sus órdenes penales internos.

Antes de la promulgación de la ley 599 del año 2000, que estableció el nuevo Código Penal, en Colombia no existía una legislación específica sobre infracciones al DIH. El Código Penal Colombiano vigente del año 2000 contiene una parte que se denomina "Delitos contra personas y bienes protegidos por el Derecho Internacional Humanitario". ${ }^{52}$ Estos tipos de delitos (artículos 135 - 164) pueden ser aplicados al conflicto armado interno colombiano, pues las normas no distinguen entre conflictos armados internacionales y no internacionales. ${ }^{153}$ Sujetos activos de esta clase de delitos pueden ser todas las personas que infraccionan el DIH, si el delito fuera cometido "con ocasión y en desarrollo del conflicto armado". ${ }^{154}$ Esto significa, que solamente si un miembro de un grupo al margen de la ley comete delitos conectados con el conflicto colombiano, esta persona va a estar condenada según los delitos establecidos en el Título II del Código Penal.

Por ejemplo, para ser responsable del delito de homicidio básicamente hay dos artículos en el Código Penal; el artículo 103 C.P. (homicidio "simple", con agravaciones en los artículos siguientes, especialmente el artículo 104 no. 8 y no. 10) y el artículo 135 C.P. (homicidio en persona protegida por el DIH). Por su parte, el artículo 135 C.P. solamente es aplicable, si el delito es cometido "en ocasión y en desarrollo del conflicto armado". Además, la persona, que murió, debe ser protegida por el DIH. Entonces, en caso de que en un combate un miembro de un grupo armado ilegal mate a un miembro de la fuerza pública, el autor es responsable según el artículo 103 C.P., agravado con la circunstancia establecida en el numeral 10 del artículo 104 por su calidad de funcionario público. El artículo 135 C.P. no sería aplicable, pues en el desarrollo del combate; el miembro de la fuerza pública en ese momento no es una persona protegida por el DIH. ${ }^{155}$

\footnotetext{
${ }^{151}$ Ramelli, La Constitución colombiana y el Derecho Internacional Humanitario, pág. 540.

152 Código Penal, Título II, "Delitos contra personas y bienes protegidos por el Derecho Internacional Humanitario".

${ }^{153}$ Valencia Villa, Derecho Internacional Humanitario, pág. 289.

${ }^{154}$ Todos los artículos del Título II; también Valencia Villa, Derecho Internacional Humanitario, pág. 297.

${ }^{155}$ Valencia Villa, Derecho Internacional Humanitario, pág. 345.
} 


\section{Leyes de amnistía e indultos generales}

\section{Definición}

El artículo 150 No. 17 de la Constitución colombiana establece que el Congreso "por mayoría de los dos tercios de los votos de los miembros de una y otra Cámara y por graves motivos de conveniencia pública" podría promulgar "amnistías o indultos generales por delitos políticos”. Según este artículo, las leyes de amnistía e indultos generales solamente pueden ser promulgadas por delitos políticos, los delitos comunes quedan excluidos. La idea es, que las leyes de amnistías e indultos puedan ser un estímulo para los miembros de grupos armados ilegales, de renunciar a las armas y facilitar su reincorporación a la "vida civil en los términos de una política de reconciliación”. Amnistías o indultos solamente deben ser concedidos por "graves motivos de conveniencia pública", o, en el caso de indultos, si los miembros de las organizaciones subversivas "demostrasen su voluntad de reincorporación a la vida civil. ${ }^{156}$ Sólo el Congreso puede conceder amnistías o autorizar al gobierno a conceder indultos, la potestad legislativa, que tiene el Gobierno Nacional durante Estados de excepción no incluye la competencia para conceder una amnistía general. $^{157}$

Las leyes de amnistía tienen carácter general, es decir, no se deben individualizar personas que cometieron delitos. Por ende debe cobijar a todas las personas que cometieron el delito que se encuentra establecido en la ley. En cambio, los indultos se individualizan a los delincuentes y los hechos punibles cometidos. ${ }^{158}$ La diferencia jurídica entre los dos es que la amnistía consiste en excluir el carácter de delictuoso a un determinado hecho, mientras que el indulto no excluye la responsabilidad ni la antijuricidad del hecho, sino se perdona la pena al autor del hecho. ${ }^{159}$

\footnotetext{
${ }^{156}$ Corte Constitucional, sentencia del 13 de abril de 1994; Corte Suprema de Justicia, Sala Plena, sentencia del 22 de octubre de 1981; por los indultos: Ley 104 del 30 de diciembre de 1993; Ramelli, La Constitución colombiana y el Derecho Internacional Humanitario, pág. 616.

${ }^{157}$ Corte Suprema de Justicia, Sala Plena, sentencia del 10 de mayo de 1982; Corte Constitucional, sentencia del 13 de abril de 1994; de acuerdo Ramelli, La Constitución colombiana y el Derecho Internacional Humanitario, pág. 603.

${ }^{158}$ Ramelli, La Constitución colombiana y el Derecho Internacional Humanitario, pág. 606.

${ }^{159}$ Carlos Zárate, El delito político, pág. 155.
} 
La otra diferencia es, que según el título III y el artículo 48 de la ley 104 de 1993, las infracciones graves al DIH quedan excluidas de cualquier forma de indulto por parte del gobierno colombiano (como genocidio, delitos atroces, secuestro o actos de ferocidad o barbarie). ${ }^{160}$

2. La Ley de Justicia y Paz (Ley 975 de 2005) y la sentencia C-370 de 2006 de la Corte Constitucional

En el año 2005 el legislador colombiano promulgó la Ley 975 de 2005, la "Ley de Justicia y Paz". Con la promulgación de esta ley se derogó la ley 782 de 2002 ("Ley de Indulto") con la cual, únicamente respecto de delitos políticos, se había permitido la amnistía o el indulto a miembros de grupos al margen de la ley. ${ }^{161}$

Según su artículo 2, originalmente la Ley de Justicia y Paz únicamente fue aplicable a los miembros de los grupos "que hubieron decidido desmovilizarse, es decir los grupos paramilitares (Autodefensas de Colombia - AUC). Mediante el decreto 1059 del 9 de abril de 2008, la ley también se debe aplicar a los miembros de grupos guerrilleros que se encuentren privados de la libertad y decidan desmovilizarse de manera individual. Entonces hoy en día la ley es aplicable a todos los miembros de grupos al margen de la ley que quieren desmovilizarse y que han cometido delitos en el marco del conflicto armado interno colombiano.

La Ley de Justicia y Paz fue promulgada por el Congreso colombiano en el año 2005 como parte de la "Justicia Transicional" con el fin de aclarar y reconciliar la grave violencia entre grupos armados ilegales, Fuerzas Militares y la población civil en el conflicto armado interno colombiano, así como desmovilizar los grupos paramilitares (artículo 1, 2 ley 975 de 2005). Se quiere entonces, establecer un procedimiento de la reincorporación a la sociedad, la reconciliación de la población civil y el regreso de los miembros de grupos armados al margen de la ley a una vida civil. ${ }^{162}$ Guerrilleros y paramilitares están sometidos a una "pena alternativa" de máximo ocho y mínimo cinco años, sin importar la cantidad y

\footnotetext{
${ }^{160}$ Ramelli, La Constitución colombiana y el Derecho Internacional Humanitario, pág. 615.

${ }^{161}$ Aponte, Justicia de Transición - Colombia, pág. 246.

${ }^{162}$ Aponte, Justicia de Transición - Colombia, pág. 245.
} 
gravedad de sus crímenes (artículo 29 ley 975 de 2005). Según la ley 975 de 2005, los miembros de grupos subversivos, que quieren ser sometidos a esta ley, deben realizar primero una confesión o versión libre indicando los delitos que habían cometido. En el proceso la Fiscalía debe verificar los hechos y el juez por su parte debe otorgarle una pena alternativa benigna. Respecto de la determinación jurídica del delito, para que los acusados sean condenados; el delito debe ser "concierto para delinquir agravado" (art. 340 C.P.). Todos los delitos cometidos por los acusados, si son confesados libremente, quedan consumados y subsumidos en este delito.

Cabe anotar que la Ley de Justicia y Paz no es una ley de amnistía o indulto. Los delitos que caen en la competencia de la ley son aquellos referidos a crímenes de guerra, de lesa humanidad, el narcotráfico y el terrorismo, es decir, se trata de delitos que por su naturaleza no admiten amnistía e indulto. ${ }^{163}$ Además la ley no elimine la pena, sino establece una pena alternativa rebajada. La ley tuvo su base en un proyecto de alternatividad penal del año 2003 con el cual la rebaja de penas y la sustitución de estas por penas alternativas eran totales. El legislador colombiano, después de una gran presión de la comunidad internacional, tenía que cambiar y mejorar este reglamento y ajustarlo a los requisitos mínimos de verdad, justicia y reparación. ${ }^{164}$ En teoría, se trata entonces de una norma que puede promover la paz, porque se da la posibilidad a los miembros de grupos armados de salir del conflicto en condiciones favorables y al mismo tiempo las víctimas reciben reparaciones.

Sin embargo, también la versión del año 2005 de la Ley de Justicia y Paz ha tenido muchas críticas a nivel nacional e internacional. La idea de la ley fue así mismo, proteger los derechos de las víctimas, pero en realidad las condiciones para obtener la generosa pena alternativa fueron poco exigentes. En la aplicación de la primera versión de la ley, confesiones falsas o incompletas por parte de los acusados, no implicaban la pérdida de ese beneficio. La crítica fue, que la ley no tenía los "dientes necesarios" para proteger efectivamente los derechos e intereses de las víctimas; la ley entonces sería una forma de

\footnotetext{
${ }^{163}$ Ibíd, pág. 252.

${ }^{164}$ Ibíd, pág. 245.
} 
impunidad disfrazada. ${ }^{165}$ También el Consejo de la Unión Europea criticó en el año 2005, que con esta ley las estructuras colectivas paramilitares no se debilitan y que también para delitos atroces solamente se impondrían bajas penas. ${ }^{166}$

Al fin, la Ley de Justicia y Paz fue demandada ante la Corte Constitucional. La Corte, en su sentencia del 18 de mayo de 2006 estableció, que de acuerdo al fin que buscaba la norma, de manera general el castigo penal alternativo por crímenes atroces era exequible, pero la desmovilización de los grupos armados, la verdad y la indemnización de las víctimas eran elementos absolutamente necesarios. Así, según la Corte Constitucional, "el hecho de que un Estado atraviese por difíciles circunstancias que dificulten la consecución de la paz [como es el caso de Colombia] no lo liberan de sus obligaciones en materia de justicia, verdad, reparación y no repetición, que emanan de la Convención Americana de Derecho Humanos." ${ }^{167}$ La sentencia entonces corrigió la Ley de Justicia y Paz en los puntos que violaban estas obligaciones. Por ejemplo hoy en día, si el acusado omite contar en la versión libre su participación en un crimen, este pierde automáticamente el derecho al sometimiento a esta ley y a la pena alternativa. También la sentencia establece que ahora "los miembros del grupo armado organizado al margen de la ley, a quienes se aplique la ley 975 de 2005, responden con su propio patrimonio para indemnizar a las víctimas de los actos violatorios de la ley penal por los que fueren condenados."

Uprimny afirma, que las modificaciones de la Ley de Justicia y Paz, impuestas por la decisión de la Corte Constitucional, comparada con su primera versión, han logrado un mejor equilibrio entre los derechos de las víctimas y los beneficios que reciben los acusados. También la obligación de la veracidad de las versiones libres de los acusados, facilita la capacidad del Estado colombiano de aclarar la verdad de los crímenes sucedidos en el conflicto colombiano. ${ }^{169}$

\footnotetext{
${ }^{165}$ Uprimny, Las leyes de justicia y paz; Aponte, Justicia de Transición - Colombia, pág. 297.

${ }^{166}$ Consejo de la Unión Europea, Mitteilung an die Presse 12514/05

${ }^{167}$ Corte Constitucional, sentencia C-370 de 2006.

${ }^{168}$ Corte Constitucional, sentencia C-370 de 2006.

${ }^{169}$ Uprimny, Las leyes de justicia y paz.
} 
Además, la Sala de Casación Penal de la Corte Suprema de Justicia en su sentencia del 11 de julio de 2007 también estableció, que la justicia de transición se trata de un mecanismo que reconoce "una tensión entre el objetivo social de lograr un tránsito efectivo hacia la paz o la democracia, y los derechos de las víctimas a que las violaciones de derechos sean investigadas, enjuiciadas y castigadas por el Estado, y a que se logra una efectiva reparación". ${ }^{170}$

Sin embargo, es importante añadir, que es muy complicado encontrar un equilibrio entre la justa sanción de los autores de los crímenes y la disposición a negociar de los grupos armados. La Ley de Justicia y Paz intenta lograr un equilibrio entre los muy distintos intereses de autores y víctimas que al fin puede ser una oportunidad para lograr la paz. La ley no es completamente perfecta y puede generar resultados poco satisfactorios para un estado de derecho. Además tampoco en todos los casos puede lograrse un perfecto equilibrio entre los intereses. El proceso de reconciliación y de la justicia de transición es un juego riesgoso, por las decepciones que pueden resultar. Toda decepción o fracaso de las expectativas creadas por el proceso de paz generará al fin, mayor violencia. ${ }^{171}$

No obstante, tal vez la Ley de Justicia y Paz puede ser un paso para una reconciliación entre la población civil en Colombia que ha sido afectada por el conflicto desde hace muchos años. El enfrentamiento crítico con asuntos del pasado en todos los países del mundo requiere grandes esfuerzos y mucho tiempo. También el caso de Sudáfrica y la superación de la Apartheid o el caso de Alemania y su superación de la dictadura de los nazis, muestran lo difícil que puede ser y cuanto tiempo se necesita para la superación del pasado.

Es claro, que también en el caso colombiano la superación del pasado o, más bien, la superación de un presente conflicto y la reconciliación entre la población civil va a necesitar muchos años más. La justicia de transición puede soportar este proceso pero la clara voluntad política para lograr paz en Colombia es imprescindible.

\footnotetext{
${ }^{170}$ Corte Suprema de Justicia, Sala de Casación Penal, sentencia del 11 de julio del 2007, tambien Aponte, Justicia de Transición - Colombia, pág. 252.

${ }^{171}$ Aponte, Justicia de Transición - Colombia, pág. 299.
} 


\section{Capítulo D. Reflexiones finales y conclusiones}

Luego de lo analizado durante el curso de esta investigación, se puede observar que diferentes y variados factores tanto en el DIH como en el derecho interno colombiano desempeñan un rol importante para el tratamiento de miembros de grupos al margen de la ley en Colombia.

En este capítulo pretende resumir los resultados del análisis realizado en cada uno de los capítulos anteriores.

\section{Capítulo A}

Dogmáticamente, según el protocolo adicional II de las Convenciones de Ginebra, en Colombia existe un conflicto armado interno. Esta norma contiene la definición más estricta, entonces se puede predicar, según las otras definiciones del DIH, la existencia de este tipo de conflictos.

\section{Capítulo B}

Ninguno de los grupos armados ilegales que hoy en día existen en Colombia está reconocido, ni debería serlo, como beligerante, ya que estos no cumplen con las condiciones para obtener tal reconocimiento.

En el derecho penal colombiano los miembros de estos grupos son tratados como "simples" criminales. No obstante surge la pregunta, sí este es el mejor tratamiento, desde el punto de vista penal, para los partícipes directos del conflicto interno colombiano.

La posibilidad del reconocimiento de un grupo armado al margen de la ley como beligerante surge de una época (siglo XIX), en la que lucharon grupos armados claramente definibles (o definidos) y con fines políticos igualmente claros. 
En el caso colombiano la aplicación de la beligerancia es compleja, ya que las normas y reglas que se establecen para otorgar dicho estatus son muy rígidas. Por otra parte, se puede considerar que el caso colombiano requiere nuevas categorías del derecho internacional humanitario. En un conflicto permanente, que se presenta desde hace tantos años, en el que se mezclan ideologías políticas distintas, intereses económicos criminales, tácticas guerrilleras y acciones terroristas, en el que tampoco es claro, si los insurgentes aún persiguen fines políticos y tienen el soporte en la población civil, discusiones sobre el reconocimiento de un grupo beligerante según reglas tradicionales del DIH, probablemente carecen de sentido. Tal vez, las normas internacionales vigentes no caben bien a un caso tan complejo y prolongado como el de Colombia.

\section{Capítulo C.}

En el derecho penal colombiano los miembros de los grupos armados ilegales en Colombia generalmente son tratados como criminales comunes. Sin embargo, hay unas diferencias por la Ley de Justicia y Paz que, si los acusados se someten bajo esta ley, les imponen una pena alternativa a la prevista en el Código Penal.

La categoría de delito político en el derecho penal colombiano produce controversias. Puede ser, que los grupos guerrilleros colombianos, en la interpretación tradicional del término "guerrilla", entienden su "guerra contra el Estado" como una lucha por los derechos de sectores de la población colombiana y que cuentan con su apoyo. Esta interpretación podría generar una inclinación a privilegiar, en la normatividad penal, a los autores de crímenes cometidos por los grupos armados al margen de la ley, que tienen fines políticos, debido a sus motivos altruistas. No obstante, como también ha señalado el expresidente Uribe (ut supra), un estado democrático debe preguntarse, si quiere privilegiar crímenes que debilitan el gobierno regular y que son cometidos en contra de su propia existencia, teniendo en cuenta que en una democracia hay otras posibilidades participativas de lograr cambios políticos de manera pacífica. Entonces los actos violentos generalmente deberían ser prohibidos. Si el autor actúa con motivos egoístas o con motivos altruistas no debe importar. 
Además, debido a la controversial discusión que existe en Colombia a la luz del derecho penal, se notan claramente las dificultades de delimitar y separar las dos categorías de delitos (delito común, delito político). Muchas veces los delitos políticos aparecen junto a formas de criminalidad "simple" que por las circunstancias no es fácil de separar. Por ejemplo, en casos de atentados contra instituciones estatales, los autores frecuentemente no quieren producir daños colaterales en la población civil, pero sin embargo aceptan la posibilidad de que esto ocurra (dolo eventual). En estos casos los delitos no deben recibir un tratamiento benévolo, por los motivos altruistas de los autores. En un estado moderno la categoría del delito político debe ser abandonada, pues, ya que la democracia puede correr el peligro de debilitarse.

Este trabajo busca, desde una visión dogmática, describir el tratamiento penal para miembros de grupos armados ilegales en Colombia, según la situación jurídica vigente en el DIH. La tesis no quiere valorar los resultados, que produce el procedimiento según esta situación legal vigente. La pregunta, si la rigurosa aplicación de las normas del DIH en el caso colombiano tiene sentido o si más bien el caso colombiano requiere una nueva categoría del DIH, es demasiado amplia para analizarla en total en este trabajo.

Las posibilidades del derecho, de aportar para conseguir la paz, son muy limitadas. Las normas y reglas internacionales del DIH persiguen la finalidad de establecer una forma de ordenamiento jurídico en conflictos armados y prohibir actos de crueldad por las partes contrarias. Sin embargo, la posibilidad del derecho de evitar conflictos armados internos es escasa.

La justicia de transición con la Ley de Justicia y Paz en Colombia puede ser un paso para establecer la paz en el país. También los procedimientos legales en juicios penales contra los autores de crímenes alrededor del conflicto armado contribuyen a mejorar la confianza de la población en el estado del derecho y en la democracia. No obstante, para terminar, siempre es la voluntad política y la libre disposición a negociar de todas las partes del conflicto, lo que tiene efectos persistentes en el camino hacia la paz. Es de esperar que el proceso de paz iniciado en Colombia continúe y a largo plazo, todas las partes logren una solución pacífica del conflicto. 


\section{Bibliografía}

\section{Libros, entrevistas, noticias}

Alston, Philip

Valencia Villa, Alejandro

Aponte Cardona, Alejandro

Bolaños Enriquez, Tania Gicela

Caracol Noticias

Castro Ospina, Sandra Jeannette

Comisión Internacional de

Juristas/Comisión Andina de Juristas
Bericht des Sonderberichterstatters über außergerichtliche, summarische oder willkürliche Hinrichtungen, ONU - Asamblea General, 28.05.2010

En Conflicto Armado y Derecho Humanitario, 2a Edición, Tercer Mundo Editores, IEPRI (UN), Comité Internacional de la Cruz Roja, 1997

Justicia de Transición - Colombia, en Justicia de Transición - Informes de América Latina, Alemania, Italia y España, Konrad-AdenauerStiftung, 2009, pág. 235 y ss.

El derecho internacional humanitario ante los conflicto modernos - ¿Amenaza terrorista?, agosto 2008, Universidad de Heidelberg, Alemania

Noticias de Caracol, http://www.noticiascaracol.com/politica/video217138-santos-reitera-no-se-puede-negar-hayconflicto-armado-colombia, (revisado en febrero 2012)

Delitos contra el régimen constitucional y legal en Lecciones de Derecho Penal - Parte Especial, Universidad Externado de Colombia, 2003

Violencia en Colombia, 1990 
Consejo de la Unión Europea

Cullen, Anthony

Departamento Nacional de Planeación

El Espectador

El Tiempo

El País

Ferro H, Juan José

García Amado, Juan Antonio
Mitteilung an die Presse (informe a la prensa) 12514/05, 2005, revisado en http://www.consilium.europa.eu/ueDocs/cms Data/docs/pressData/de/gena/86515.pdf (revisado en mayo 2012)

Key developments affecting the scope of internal armed conflict in international humanitarian law, Military Law Review, Vol. 183,2005

Hacia un Estado comunitario, Plan Nacional de Desarrollo (2002-2006), 2002

¿Estrategia o buena voluntad de paz?, El Espectador, 26 de febrero de 2012, http://www.elespectador.com/impreso/temadel dia/articulo-328935-estrategia-o-buenavoluntad-de-paz, (revisado en mayo 2012)

Con beligerancia, las Farc tendrían que dejar de secuestrar: Chávez, El Tiempo, 14 de enero de 2008 http://www.eltiempo.com/archivo/documento/ MAM-2792698, (revisado en mayo 2012)

Colombia protestará ante Ecuador por insistencia en beligerancia de las FARC, El País, 2008, http://historico.elpais.com.co/paisonline/notas/ Abril242008/colprotesta.html, (revisado en abril 2012)

Existencia de un Conflicto Armado Interno: Quien decide?, Revista de Derecho Publico No. 26, Universidad Los Andes, febrero 2011

Delito político - Al hilo de la Sentencia de la Corte Suprema de Justicia de Colombia de 11 de 11 de julio de 2007, Procuraduria General de la Nacion; Instituto de Estudios del Ministerio Público, 2007 
Gonzáles Mongui, Pablo Elías

(Compilador)

Herdegen, Matthias

Human Rights Watch

Ipsen, Knut

Kelsen, Hans

Krieger, Heike

Libardo Botero Campuzano (Compilador)

Libardo Botero Campuzano (Compilador)
Derecho Internacional Humanitario, Universidad Libre de Colombia, 2007

Völkerrecht, 10a Edición, Verlag C. H. Beck, 2011

Heredores de los paramilitares - La nueva cara de la violencia en Colombia, febrero de 2010,

http://www.hrw.org/reports/2010/02/03/hereder os-de-los-paramilitares-0 (revisado en mayo 2012)

Völkerrecht, Edición. 4, Verlag C. H. Beck, 1999

Principios de Derecho Internacional Publico, Editorial Et Ateneo, Buenos Aires, 1952

Deutschland im asymmetrischen Konflikt: Kriegsrechtliche Grenzen der Anwendung militärischer Gewalt gegen Taliban-Kämpfer in Afghanistan, Online-Beiträge zum Völkerund Verfassungsrecht Nr. 2/2010, Articulo publicado en: http://www.jura.fuberlin.de/einrichtungen/we3/professoren/ls_kri eger/berliner_online beitraege/Nr2-

10_Krieger/index.html, (revisado en mayo 2012)

Crímenes altruistas - Las razones del presidente Uribe para abolir el delito político en Colombia, Fundación Centro de Pensamiento Primero Colombia, 2007

La estratagema terrorista: Las razones del presidente Uribe para no aceptar la existencia de un conflicto interno armado en Colombia, Fundación Centro de Pensamiento Primero Colombia, 2008 
Londoño Ulloa, Jorge Eduardo (Compilador)

Oficina en Colombia del Alto Comisionado de las Naciones Unidas para los derechos humanos

Pabón Parra, Pedro Alfonso

Pizarro Leongómez, Eduardo

Pizarro Leongómez, Eduardo

Quintana, Juan José

Ramelli Arteaga, Alejandro

Ramelli Arteaga, Alejandro

Singer, David/Small, Melvin
Derecho internacional humanitario, conflicto armado y tratamiento de las victimas,

Ediciones Uniboyacá, 2002

Informe del Alto Comisionado de las Naciones Unidas para los derechos humanos sobre la situación de los derechos humanos y el derecho internacional humanitario den Colombia, 2011

Manual del derecho penal, parte general parte especial, 7a edición, Ediciones Doctrina y Ley, 2005

Las Farc y el reconocimiento de beligerancia, El Tiempo, 09.03.2011, Articulo publicado en http://www.eltiempo.com/politica/ARTICULO -WEB-NEW_NOTA_INTERIOR-

9318340.html (revisado en mayo 2012)

Una democracia asediada, Grupo Editorial Norma, 2004

Derecho Internacional Público

Contemporáneo, Ediciones Jurídicas Gustavo Ibañez, 2001.

Derecho Internacional Humanitario y estado de beligerancia, 2a edición, Universidad Externado de Colombia, 2004

La Constitución Colombiana y el Derecho Internacional Humanitario, Universidad Externado de Colombia, 2000

Correlates of War Project: International and Civil War Data, 1816-1992, 1994, Abstract publicado en http://www.icpsr.umich.edu/icpsrweb/ICPSR/st udies/9905 (revisado en mayo 2012) 
Uprimny Yepes, Rodrigo

Uprimny Yepes, Rodrigo

Uprimny Yepes, Rodrigo

Uribe Vélez, Álvaro

Valcárcel Torres, Juan Manuel

Valencia, Felipe Ortiz

Valencia Villa, Alejandro
¿Existe o no Conflicto Armado en Colombia?, 2005, Articulo publicado en http://www.dejusticia.org/index.php?modo=int erna\&tema=justicia_transicional $\&$ publicacion $=$ $\underline{355}$, (revisado en mayo 2012)

Las leyes de justicia y paz, 02.05.2010, Artículo publicado en http://www.dejusticia.org/index.php?modo=int erna\&tema $=$ justicia transicional $\&$ publicacion $=$ $\underline{818}$, (revisado en abril 2012)

Sobre el conflicto armado en Colombia, 09.05.2011, Artículo publicado en http://www.dejusticia.org/index.php?modo=int erna\&tema=cultura juridica_y_educacion $\& p u$ blicacion $=950$, (revisado en marzo 2012)

¿Debe existir el delito político en Colombia?, Artículo publicado en http://www.presidencia.gov.co/prensa new/sne /2005/mayo/18/08182005.htm, (revisado en mayo 2012(

Beligerancia, Terrorismo y Conflicto Armado: No es un juego de palabras, Articulo publicado en: Internacional Law, Revista Colombiana de Derecho Internacional, No. 13 (noviembre 2008), pág. 363-390

El reconocimiento de beligerancia frente al conflicto armado con las FARC-EP, Tesis de Grado, Universidad Colegio Mayor de Nuestra Señora del Rosario, Bogotá 2008

Derecho internacional humanitario conceptos básicos; Infracciones en el conflicto armado colombiano, Oficina en Colombia del Alto Comisionado de las Naciones Unidas para los derechos Humanos, Bogotá 2007 


\section{Jurisprudencia}

- Corte Constitucional, sentencia C-179 de 1994

- Corte Constitucional, sentencia C-225 de 1995

- Corte Constitucional, sentencia C-009 de 1995

- Corte Constitucional, sentencia C-456 de 1997

- Corte Constitucional, sentencia C-991 de 2000

- Corte Constitucional, sentencia T-025 de 2002

- Corte Constitucional, sentencia C-370 de 2006

- Corte Constitucional, sentencia C-291 de 2007

- Corte Suprema de Justicia, Sala Plena, sentencia del 22 de octubre de 1981

- Corte Suprema de Justicia, Sala Plena, sentencia del 10 de mayo de 1982

- Corte Suprema de Justicia, Sala de casación penal, sentencia del 26 de mayo de 1982

- Corte Suprema de Justicia, Sala Plena, sentencia del 10 de febrero 1983

- Corte Suprema de Justicia, Sala de casación penal, sentencia del 7 de abril de 1995

- Corte Suprema de Justicia, Sala de casación penal, sentencia del 11 de julio de 2007 